$1-1-1903$

\title{
Rural water supply: with a study of the Monongahela River supply at Morgantown
}

Charles D. Howard

Follow this and additional works at: https://researchrepository.wvu.edu/ wv_agricultural_and_forestry_experiment_station_bulletins

\section{Digital Commons Citation}

Howard, Charles D., "Rural water supply : with a study of the Monongahela River supply at Morgantown" (1903). West Virginia Agricultural and Forestry Experiment Station Bulletins. 89.

https://researchrepository.wvu.edu/wv_agricultural_and_forestry_experiment_station_bulletins/89 @ WVU. It has been accepted for inclusion in West Virginia Agricultural and Forestry Experiment Station Bulletins by an authorized administrator of The Research Repository @ WVU. For more information, please contact ian.harmon@mail.wvu.edu. 




\section{WEST VIRGINIA UNIVERSITY \\ AGRICULTURAL EXPERIMENT STATION, \\ MORGANTOWN, W. VA.}

\section{Rural Water Supply.}

WITH

A Study of the Monongahela River Supply at

Morgantown.

By C. D. HOWARD.

[The Bulletins and Reports of this Station will be mailed free to any citizen of West Virginia upon written application. Address, Director of Agricultural Experiment Station, Morgantown, W. Va.] 


\section{THE REGENTS OF THE WEST VIRGINIA UNIVERSITY}

NAME OF REGENT.

P. O. ADDRESS.

Hon. W. J. W. Cowden, .................. Wheeling

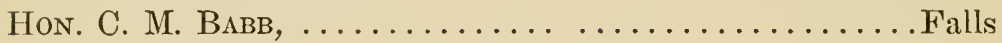

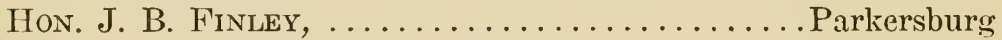

Hon. D. C. GaLlaher, ................... Charleston

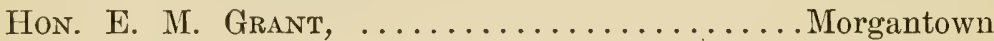

Hon. J. M. Hale, . .................. Princeton

Hon. C. E. Haworth, . . . . . . . . . . . . Huntington

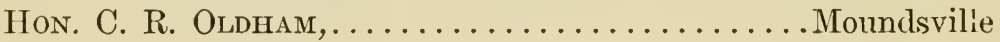

Hon. J. R. Trotter, .................... Buckhannon

President of the Board of Regents, ........W. J. W. Cowden President of the University,............. B. B. Purintor

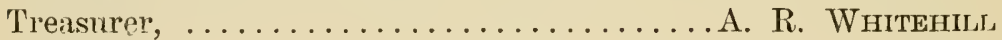

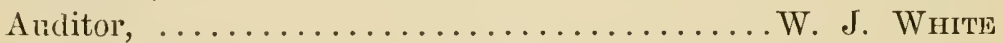

\section{STATION STAFF.}

JAMES H. STEWARt, A. M.,......... Director and Ágriculturist Bert H. Hite, M. S.,.......... Vice Director and Chemist John L. Sheldon, PH.D., . . . . . . . . . . Plant Pathologist W. E. Rumsey, B. S. Agr.,...........Entomologist in Charge Horace Atwood, M. S. Agr.,..........AssistantAgriculturist Chas. D. Howard, B. S.,............... Associate Chemist '1. C. Johnson, M. S.,.... Botanist and Assistant Horticulturist

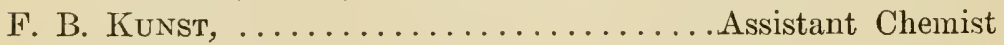
Gilbert M. John, ...............Assistant Horticulturist Fred. E. Brooks, ..................... Special Agent W. J. Wніте,. . . . . . . . . . . . . . . . . Bookkeeper

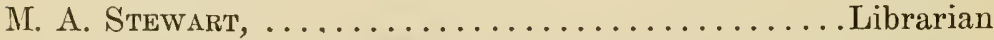

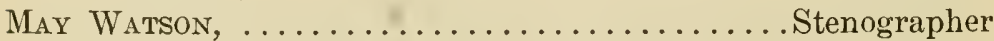


Digitized by the Internet Archive in 2010 with funding from

Lyrasis Members and Sloan Foundation 


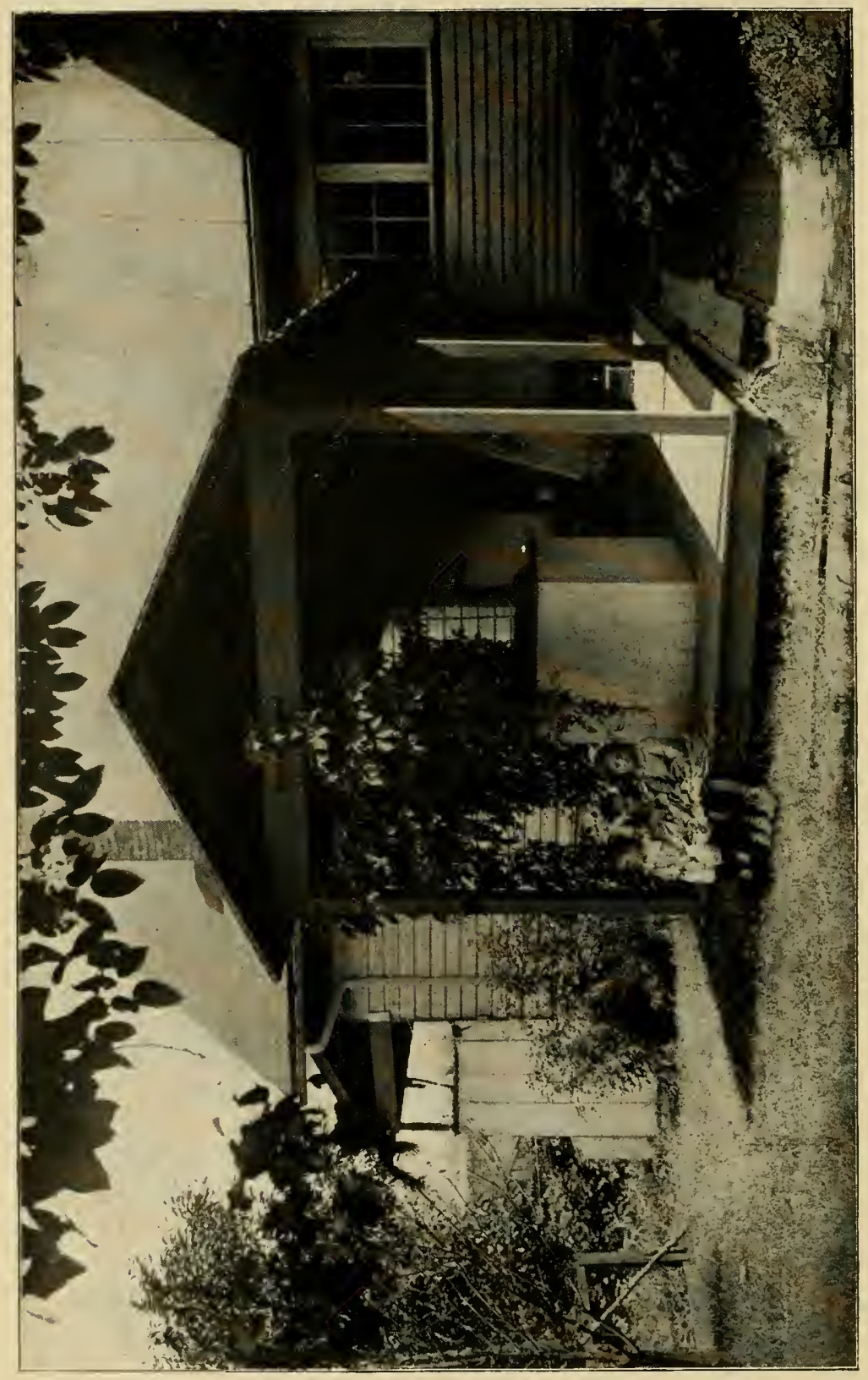

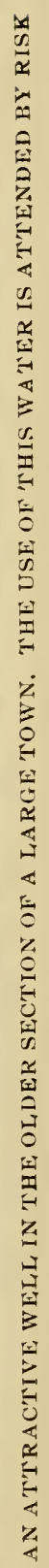




\section{RURAL WATER SUPPLY.}

"The Pioneer dreamed of the clear, cool spring gurgling from moss-grown rocks in the depths of the dell; the Farmer Boy dreamed of the picturesque well sweep or creaking windlass, and the 'moss-covered bucket that hung in the well'; but both dreams have faded; for the spring is dried up, and in the well lurks a poison sweeter than poppies, deadlier than the nightshade."-

McGee.

In comparing the advantages of a country life with those of an existence in the city, one nowadays frequently encounters the argument that the eity resident enjoys better health protection than his country brother. This is undoubtedly true, to the extent that water and the carelessness and ignorance of the individual are factors in the public health. The crowding together of people in cities renders imperative a system of municipal care and oversight. The water supply is usually carefully selected and its purity zealously guarded; there is an efficient sewerage system to dispose of the city's waste; hospitals and pest houses are maintained; a laboratory of hygiene provides for the inspection of milk, the detection of food adulteration, and the prompt and exact diagnosis of disease.

Several of the older states now specially provide for the examination of water supplies, both rural and municipal, but while compulsory periodic inspection of such has been the rule for some time in Germany it is not until recently that anything of this nature has been enacted in the United States. The legislature of 
North Carolina, at its last session, established a precedent for other states to follow in passing a law which provides for the compulsory quarterly, chemical and bacteriological examination of all public water supplies within the state. Where bad conditions are found, this law provides that if proper steps are not taken within thirty days to remedy such, there is to be publisherl in the local papers, "a plain statement of the facts for the information and protection of citizens using water."

Such legislation, however, is not for the farmer; the latte: has to take care of his own health. Whereas, in the city, the fact that a half million people drink the same water, renders it essential that its quality be above suspicion, in the country there are as many different water supplies as there are dwellings. This fact of itself, however, is, in the majority of cases, no good reason why the farmer's family should so often drink impure water. Rather, carelessness, ignorance, indifference even, are mainly responsible. Those who give the matter any especial consideration are usually satisfied-indeed, convinced of the excellent character of their supply provided it be clear, sparkling and withont disagreeable taste or odor.

That an abundance of perfectly wholesome drinking water is not at the command of a considerable proportion of West Virginia farmers, is in accord with the observations and experience of those competent to judge; that such a supply might be secured upon almost every farm in the State, nobody can deny. For, while a corrupt municipal government or private water company may be responsible for a high typhoid death rate among a helpless city population, the farmer controls his own destiny in this respect. If his well carries the germs of fever or other poison it is because he wills it to be so.

The usual and quite natural practice is to put down a well wherever it will be the most convenient with reference to the kitchen or as a supply for the stock. Its close proximity to barnyard, sink-drain, vault, or cess-pool is seemingly not a matter of any great moment even with many otherwise intelligent persons. 
Indeed, there are people who will claim that water from a weli thus located is "healthy," and will hasten to silence any derogatory imputations with the argument that its water has been in use for a generation. The fact that the farmer and his family are healthy, not because of such water but in spite of it, speaks much in favor of simple, wholesome living combined with plenty of out-of-door exercise.

The action of soil as a remover of dead matter from water or drainage, is not so thoroughly understood by the public as it should be, although most people at the present day know that by passage through the ground, this purification is in some way brought about. In order to make clear to the general reader the processes by which refuse material is destroyed in nature, it will be necessary to give a brief explanation of the action of bacteria, or "germs," as they are popularly known. These may be dividert into two general classes, namely: "good" germs and "bad" germs; while the former class is decidedly the larger of the two, yet the "bad", following the universal law of good and evil, is much the more conspicuous; indeed, so much more so that it has not been so very long since the possibility was admitted of the existence of a beneficent class.

As to the abiding places of bacteria they are to be found wherever there is any form of living matter and usually they oceur in almost countless numbers. It is the function of a large number of species to destroy and clear away all dead material by converting it into gases. These are the putrefactive bacteria. Others, the parasitic class, inhabit animal organisms;.varieties that cause disease in such are said to be pathogenic; while still another class commonly occuring in the soil, leads a symbiotic existence, furnishing nitrogen to plants in return for a home in their rootlets.

The primary action of a soil through which water pereolates is that of a filter, or strainer. If it is to do more than merely remove suspended material from the water, such soil must contain a sufficient number of the putrefactive bacteria, not only to de- 
stroy the dissolved organic matter but to eombat and annihilate the dangerous parasitic germs always present in the refuse of animal existence. In order that the putrefactive bateria may do this work a supply of oxygen from the atmosphere is indispensible. Consequently, it will be seen that if the pores of the soil bscome clogged with water, or sewage material these germs die or are overporrered by the superior numbers of the parasites, and the water as it finally issues into well or spring, while it may be quite clear is, nevertheless, impure: that is, it contains undestroyed organic matter. accompanied by bacteria of various kinds, including very possibly specific disease germs.

Were the passage of ground water through soil always a process of percolation through a eompaet mass of earth, then cases of impure well or spring water might be far less numerous. In reality regular channels usually exist throngh which there is an unobstrueted flow. These channels commonly oceur upon the top of the underlying shale, clay, or rock,-such strata preventing the further downward passage of water. As, under such circumstances, any drainage that might find its way into these regular water channels could flow for many rods with little purification, it is of prime importance in locating a well, to take into consideration the general slope with reference to possible sources of contamination.

With this end in view it is always desirable to have the well or spring on a higher level than the buildings. Drainage from the kitchen sink should be conducted in pipe drains as far as possible from the house and finally allowed to flow out upon the surface of the ground where air and sunlight and rank plant growths remove any possibility of danger from this souree.

The use of a cess-pool ought not to be tolerated under any circumstances. The only place where it is possible to locate one at a sufficient distance from one's own or one's neighbor's well is on the farm and here they are unnecessary. The use in villages of even the cemented brick form is unsafe, as such is apt to become leaky sooner or later. 
The old style of filtering cess-pool unfortunately still in vogue in many of the smaller villages, ought to be utterly condemned. The very nature of its operation involves the distribution over a considerable area, of noxious drainage material, with which the ground becomes saturated, and not only does the latter then exhale dangerous malarial vapors, but the wholesale pollution of neighboring wells is unavoidable. The installation of a sewer system in any community should always be simultaneous with that of the water supply. Until the former is secured, the dry earth closet arrangement is the only form that ought to be tolerated by either villager or farmer. The vaults of such closets should be tightly cemented and a little dry earth added each day to absorb moisture and destroy odors. In like manner, on the farm the desirability is evident of properly eemented barn eeilars, and the use of composting material with the stable manure. 


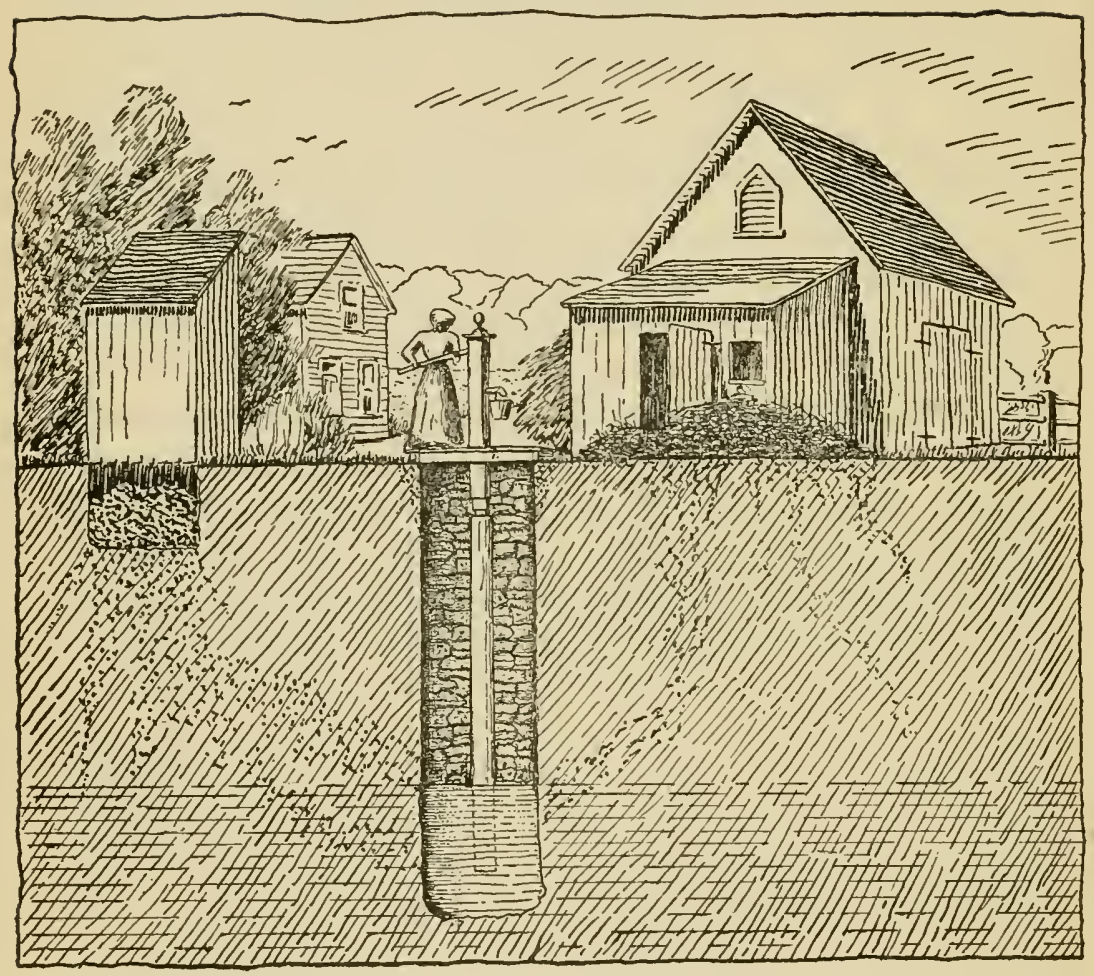

Fig. 1. - The shallow barnyard well, with privy vault and manure heaps near by. The water is likely to receive fluid from these at any time. (From Smith's Sewage Disposal on the Farm, Farmers' Bulletin No. 43, U. S. Department of Agriculture.)

The drinking water supply should not be located in or near a barnyard or cultivated soil. The ground immediately surrounding should be in grass and no waste or refuse of any kind allowed about the eurb. In order to prevent the possibility of any surface wash or drainage, the well, unless a driven one, ought to be cased down to the water level with brick or stone laid in mortar, the adjacent soil layers being thoroughly tamped. The masonry should be extended above the surface a few inches and covered by a tightly fitting platform. The latter is removed 
only when the well is to be cleaned, which should occur as often as once a year. The idea that the admission of light and air to a well improves the water is erroneons. Ground water is secluded from air before it enters the well and it does not rquire it afterwards.

As regards the proper distance between the well and possible sources of pollution this is purely a matter of judgment, to be based upon such circumstances as the slope of the surface, character of the sub-soil, and the depth of the well. Generally speaking, the deeper the well the greater its possibility of acting. as a catch basin and "drawing" polluting drainage from any source of such that may be near. For this reason it is in the summer rather than in the winter that we may sometimes notice a bad taste in the water, becanse the level of the water in the well is then usually much lower and the well receives drainage from a more extended area. Then too, in winter, ground waters are not only colder and consequently more palatable, but also appreciably diluted by rains and snow. It may be said, however, that if one makes sure of perfectly tight drains and closets and the well is on higher ground, seventy-five or one hundred feet from barns or stables, there will usually be no trouble.

The attention of farmers and especially of village residents is called to the desirable features in connection with a driven well supply. The old idea that it was necessary to locate the well in a low spot of ground in order to obtain water, no longer exists, as under most conditions, it is but a matter of drilling to a moderate depth in almost any spot in order to secure an abundant supply. Portable well drilling outfits can now be obtained without much difficulty in most localities and ordinarily the cost of drilling is not great. Provided vertical cracks or fissures in the strata do not exist, the water from drilled wells, $100 \mathrm{ft}$. or more deep, is usually very pure. Such wells may be either single or double cased and if properly constructed there is very little chance for the entrance of surface drainage.

However, it must not be supposed that the water of such is 
infallibly pure, especially if the well be located in a city or a low lying district in a large town. Instanees are on record of eity driven wells several hundred feet deep which have been found to receive surface pollution, the latter penetrating the loose friable strata through which the wells were drilled. Again, the rock stratum at the bottom of a well a hundred feet deep may have its outerop in a city a mile or more away and there receive pollution, which may be conducted with but little true filtration, into the supply. Strata at the top of a hill usually occupy a lower position, geologically, and it is, therefore, evident that a well located on an elevation ordinarily receives its water from a greater stratigraphical depth and is therefore more apt to be pure than is water from a well of the same depth drilled on lower ground.

An occasional objection to water from deep strata is its un. fitness for domestic purposes due to a high content of mineral matter. Such waters are often very hard, or-and this is especially true of wells sunk in the coal measures - they may be highly alkaline, and also contain large proportions of common salt, along with sulphuretted hydrogen gas.

In those eases in country districts where a plentiful supply of pure, moderately soft water is not available, the use of roof cisterns is very advantageous and to be commended. Frequently there are waters so impregnated by salts of lime and magnesia as to be wholly unfit for washing purposes. When soap is used with such water there is developed large amounts of a greasy scum before any true lather forms, and therefore before any cleansing effect is attained. Frequently more soap is used in overcoming the hardness of the water, alone, than is subsequently required in the actual process of washing. Rain water, being quite soft, involves no such waste of material. Rain water, being best made of brick or stone, and should be carefully cemented up. It should be located a suffieient distance below the surface of the ground to avoid freezing in winter, and becoming warmed in summer. The building roofs, preferably for this purpose of slate or tin, should be kept free of any aceumulation of leaves or other 
matter. Where considered necessary for filtering purposes, a layer of sand may be interposed between the conductor pipe and the cistern proper. The latter should be cleaned at least once a year. It is best not to conduct the overflow pipe into a cess-pool or sewer where this is at all avoidable. However, in cases where it is done a thoroughly efficient, well ventilated trap should be employed to obviate all possibility of the water being rendered impure through the entrance of poisonous gases.

The use of polluted water is almost sure to cause bowei trouble or other disturbances in those unaccustomed to its use, while even in a family of vigorous constitutions who drink such water regularly, its ill-effects are very apt to be manifested sooner or later in general debility or some other impairment of health, gradual though it may be. Finally, there is always a chance of the germs of typhoid fever being brought upon the farm by some person and the water that was before, perhaps but a slow and uncertain poison, may now quickly cause acute illness.

During recent years several extensive epidemics of typhoid fever have been traced to the use of an infected milk supply. As it has been demonstrated 1 that eattle do not transmit the germ, it follows that the latter must be introduced from some other source. In nearly all these cases the farm well has been found to be polluted, and as intentional dilution of the milk supply has, of course always been strenuously denied, one is forced to the conclusion that inoculation must have arisen from the water with which the dairy utensils were washed. It is well to observe, therefore, that if all cans and pails are thoroughly scalded, as they should be during cleaning, and the subsequent common, but unnecessary process of rinsing with cold water, omitted, all possibility of infection from this source would be removed.

\section{SANITARY EXAMINATION OF WATER.}

Most people do not understand that the sanitary examination

1 Farmers' Bulletin No. 19, U. S. Dept. of Agriculture. 
of a water is quite a different matter from the analysis of a fertilizer or the assay of an ore. Samples sent in for analysis are ordinarily unaccompanied by any information whatever concernin the source or circumstances, such doubtless being considered as incompatible with an impartial decision. It is, usually assum ed that the taking of a sample consists merely in dipping up the water into almost any kind of a receptacle conveniently at hand. This Station has frequently received such contained in jugs or bottles possessing all the blended odors of a grocery or druc store, and often stoppered with corn-cobs, rags, wooden plugs, or other make-shifts. Ordinarily it is quite useless to attempt to do anything with such samples.

The public should understand that a report upon the quality of a water, involves diagnosis and not evaluation. The analysis does not mean the isolation of any specific poisons; it merely affords a series of indications, the proper interpretation of which demands a complete knowledge of the source of the water and the local surroundings. (See page 190 for instructions for sampling water.)

The general appearance of a water is often an unreliable index to its quality. Just as a wholesome drinking water may he both brown colored and slightly turbid, so the most highly polluted gromnd waters are frequently clear as erystal, and often with a by no means objectionable or distinctive taste.

The amount of solid matter found in waters varies to an enormous extent. Streams and lakes, being surface waters, carry much smaller quanities of dissolved substances than well or spring waters. The amount of solids in solution which the latter may contain depends upon the nature of the soil and rock through which it has travelled. The waters of limestone districts usually contain large quantities of lime and magnesia. Such are said to be hard, that is, they require much more soap with which to form a lather than do the softer river waters.

Hardness which may be removed by boiling is said to be temporary. Such is due to the presence of lime and magnesia carbonates, 
which are held in solution by carbonic acid gas. On boiling the latter is expelled and the lime and magnesia become insoluble. Permanent hardness, on the other hand, is due to the sulphates of lime and magnesia. For boiler use this is the more objectionable form and the most expensive one to remedy. Its removal from a water is usually effected by treatment with carbonate or phosphate of soda. Common washing soda added to permanently hard water renders it "soft," that is, by changing lime and magnesia into insoluble compounds, it accomplishes the same result as does simple boiling in the case of waters the hardness of which is temporary. A water is considered soft when the total hardness does not exceed 5 degrees; medium, wheu ranging between 5 degrees and 10 degrees, while above the latter figure is hard. These quantities (Clark's degrees) represent grains per imperial gallon of calcium carbonate, or its equivalent.

The question of hardness is one of considerable importance to laundrymen, as well as to those having the management of steam boilers. A writer* on the subject says: "The lime salts in a thousand gallons of water will destroy $1.7 \mathrm{lbs}$. of the best hard soap for each degree of hardness of the water, and this is all clear waste, as it is in addition to the dissolved (but not destroyed) soap that the washing process actually requires. In addition to this loss, the insoluble curded soap remains in the water until it comes in contact with the fabric that is being washed, when it naturally sticks to or in the fabric, and owing to its greasy nature. cannot be removed from it by rinsing, even with hot water."

*Collet: "Water Softening and Purification."

As lime is a prominent constituent of the animal body and as hard water is due to an excess of this substance in solution, we may generally look with suspicion upon a water that is very hard when it comes from a district containing no limestone, and especially so if other similar waters from this neighborhood are appreciably softer. However, a soft water is by no means, necessarily, a pure one.

Another figure which is always obtained in a search for pollution is the "chlorine" content. Chlorine is one of the compo. nents of common salt and as the latter is always present to a large extent in the animal secretions, the presence of abnormally large quantities of chlorine in a water is always a bad indication. This test, of course, can have no significance in the case of deep- 
ly seated waters, occuring away from the older granite formations; especially is this true of waters from the salt strata.

TOTAL SOLIDS, HARDNESS, AND CHLORINE OF DIFFERENT WATERS.

Parts in 100,000 .

\begin{tabular}{|c|c|c|c|c|c|}
\hline & & \multirow{2}{*}{ SOLIDS. } & \multicolumn{2}{|c|}{ HARDNESS* } & \multirow{2}{*}{ Chlorine } \\
\hline & & & Temporary & Total & \\
\hline & Spring, Martinsburg,....... & 34.0 & 8.0 & 18.8 & 0.84 \\
\hline & Spring, Sturgisson, ...... & 1.94 & $\ldots \ldots \ldots$ & $\ldots \ldots \ldots$ & 0.22 \\
\hline & Stream, Tibb's Run, ...... & 2.80 & ...... & 0.47 & 0.14 \\
\hline & Well, Easton, ........... & 26.30 & & 13.50 & 1.12 \\
\hline & Well, Taylor county, ...... & 13.40 & $\ldots \ldots \ldots$ & $\ldots \ldots \ldots$ & 0.14 \\
\hline & Well, Morgantown, ..... & 30.80 & 1.6 & 11.5 & 2.50 \\
\hline & Well, Morgantown, ......... & 40.00 & 2.2 & 14.5 & 3.50 \\
\hline & Deep Well, Morgantown, & 26.50 & $\therefore \ldots \ldots$ & $\ldots \ldots \ldots$ & 1.80 \\
\hline & Deep WVell, Weston, ..... & 201.40 & none & none & 75.00 \\
\hline & Salt Well, Huntington, ..... & 17650.00 & $\ldots \ldots \ldots$ & $\cdots \ldots \ldots$ & 9169.00 \\
\hline & Monongahela river, Morg't'n & 9.27 & 1.6 & 6.2 & 0.57 \\
\hline
\end{tabular}

1. Limestone district, water very hard. 2. Flows through partially disintegrated sand rock; water extremely soft. 3. Contains much salt and alkali. 4. Filtered supply; somewhat harder than normal on account of low water.

*Parts in $100,000 \times 0.7$ hardness, Clark's degrees.

The amount and the nature of the nitrogenous matter are the points of most importance in connection with a sanitary examination. This includes the determination of four different forms of nitrogen, viz.: the nitrogen of albuminoid ammonia, of free ammonia, of nitrites, and of nitrates. These nitrogen compounds represent the different stages in the destruction or oxidation of animal or vegetable material. The albuminoids are nitrogenous bodies which yield ammonia on oxidation. They are important constituents of both animal and plant tissues. Consequently, the presence of dead leaves or rotting wood in a well or spring may be responsible, as well as sewage contamination, for a high albuminoid ammonia test. Free ammonia and nitrites are present in both the atmosphere and cultivated soils. Nitrites and nitrates 
are important constituents of the soil, and serve as valuable plant food for growing crops. Experience has made it possible to base certain interpretations upon the extent of the presence of these nitrogenous compounds, governed very largely, it should be observed, by the source and nature of the water, and other circumstances. Generally speaking, it may be said that the presence of even a trace of nitrites is a suspicious indication, as such shows not only incomplete oxidation, but also that the natural course of purification of the water is being interrupted through some cause.

The presence of any considerable proportion of nitrates in a water indicates that the latter has at sometime contained a good deal of organic material, either vegetable or animal, but from which it has subsequently become freed, either wholly or in part, by oxidation. While such water may be perfectly fit to drink, yet the fact that it has had abundant aids to purification is no guarantee that it will always retain them, and consequently the use of such is generally considered unsafe. The rule of Wanklyn condemning waters containing more than 0.015 parts in 100,000 of albuminoid ammonia has but little application in the light of present day knowledge, as there are many surface waters carrying high a!buminoid ammonia due to peaty or other vegetable matter, which are considered perfectly wholesome. On the contrary it is frequently necessary to find fault with waters containing very much less of this constituent than the above figure. For this reason the same analysis which would be sufficient to condemn a well water might indicate a perfectly usable river water, and vice versa. 
Following are anlyses of a few well waters:

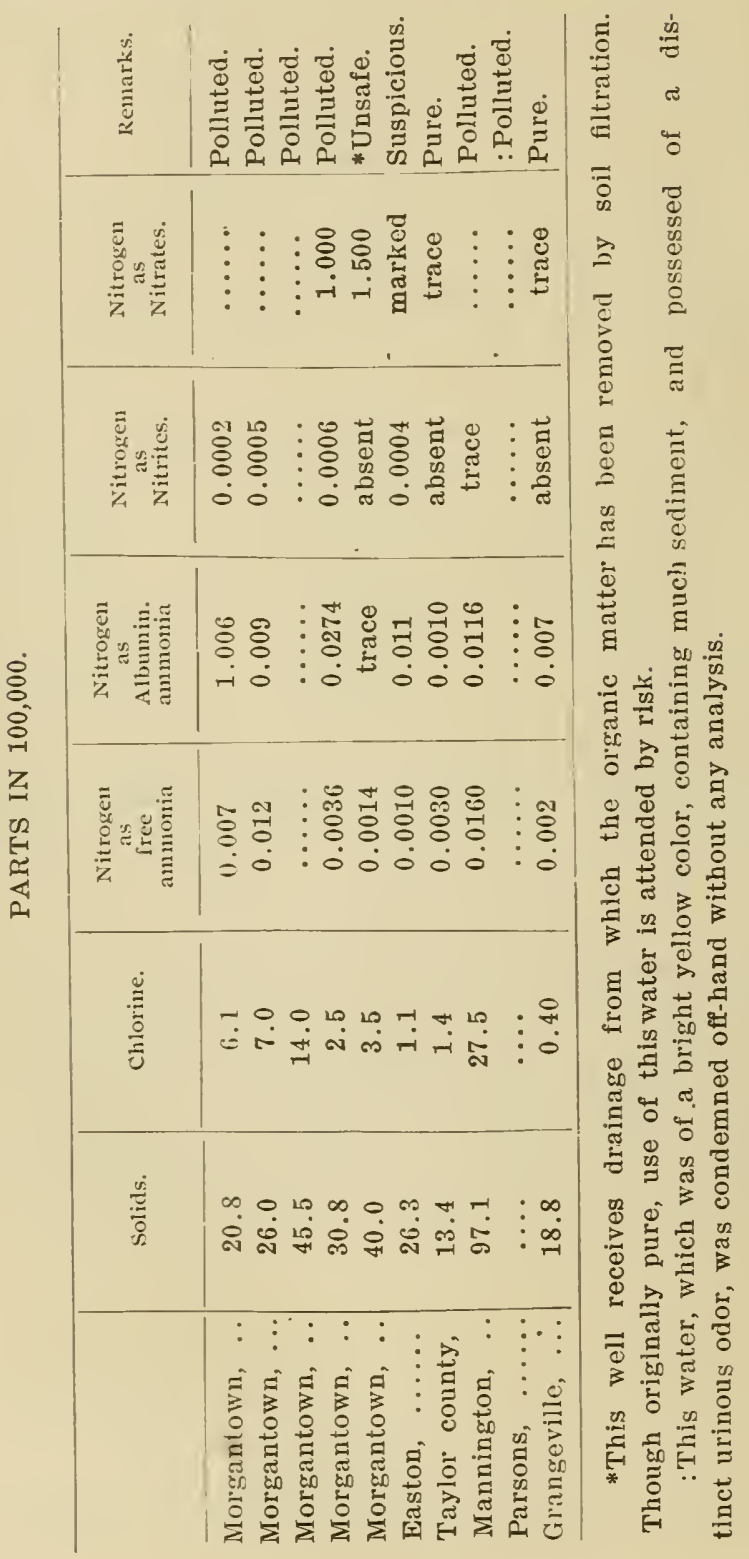




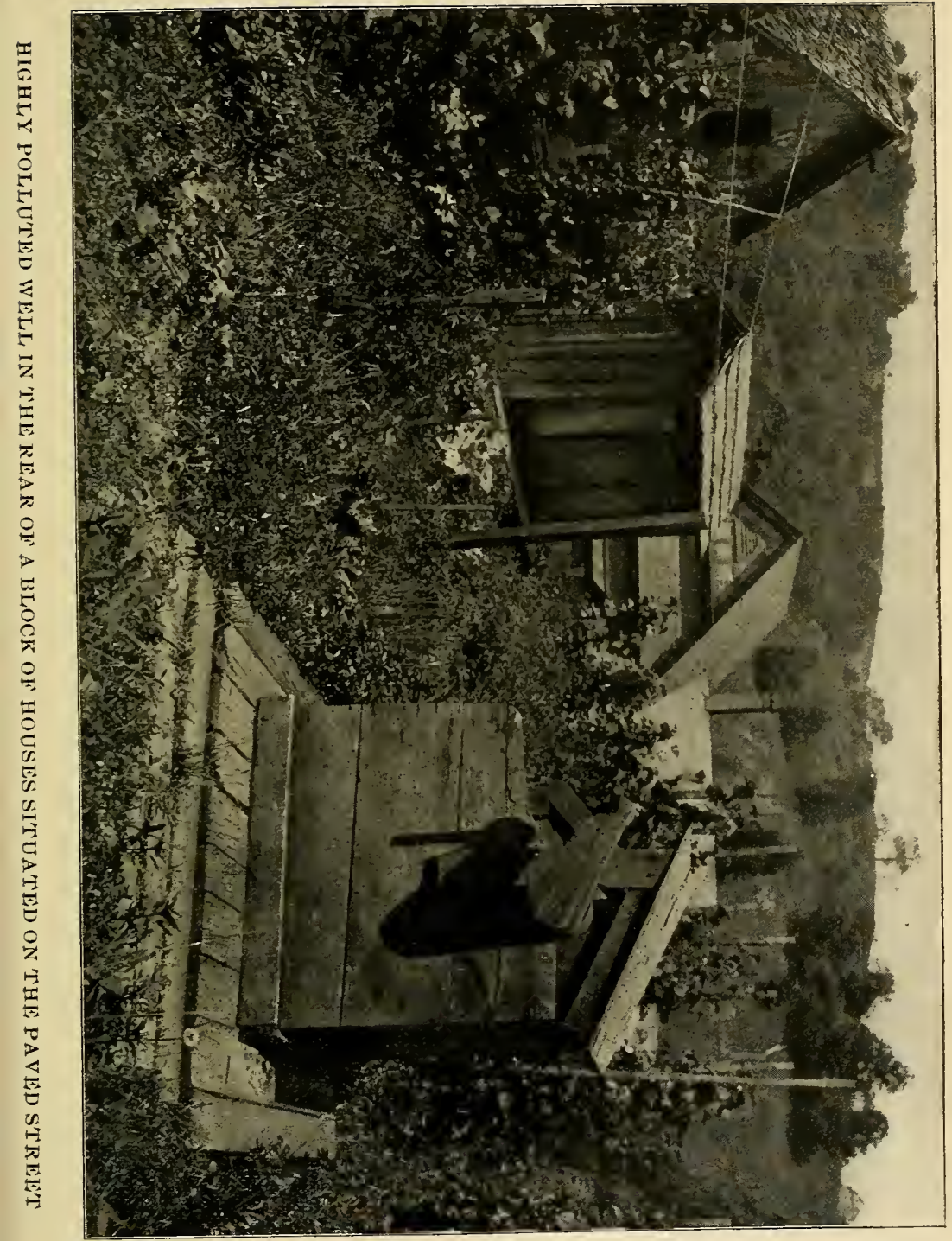



In this connection it is appropriate to decry the practice on the part of dwellers in the larger towns of clinging to the use of water from the old wells as being to their minds, in many cases, at least better and safer than the public supply. Undoubtedly the water of such is frequently clearer and colder than the latter, yet as has been pointed out, these qualities are in no wise guaranties of purity. In short, it may be accepted as axiomatic that the use of water from wells and springs thus located is invariably attended by risk. In the case of a town the size of Morgantown, with the exception perhaps of a few on the outskirts, there is probably not a`well of ordinary depth, the water of which is quite free from pollution, and is really safe and fit to drink, its appearance to the contrary notwithstanding. Certainly tha writer has never known of any such which have given entirely good analyses.

In a recent article entitled "The Selection of a Home," (Cosmopolitan Magazine), Prof. Martin, of Cornell University, says: "As the writer sits at his window, overlooking the eity in the valley, he sees literally hundreds of houses, many of them ample and with a well to do air, and not a few of them elaborate and evidently the abode of wealth-_ - and with cess-pools and wells of drinking water hobnobbing in brotherly love, in spite of the board of health, a good sewerage system, and a fair, city water supply."

Conditions such as these are duplicated in almost every prosperous, growing community,-in centers of culture and refinement as well as in those of manufacture and industry. The seriousness of their import to the public health is seldom realizert by any save physicians. While, with the public at large, one or two cases of small-pox are sufficient to occasion wide spread telror, those causes that gradually give rise to debilitated, sickly constitutions, are rarely noticed or appreciated. Even typhoid fever, which annually causes many more deaths than small-pox, has to assume the proportions of a considerable epidemic before 
it arouses public attention-perhaps for the reason that, like the poor, most communities have a certain amount of this disease a!ways with them.

\section{MARTINSBURG WATER SUPPLY.}

The following five analyses are of the Martinsburg water supply. The latter consists of a large spring which issues from under a rock at the base of a hi'l, near the town. It is understood that the water has always r,een considered excellent, though raturally very hard. The samples were all received upon the same date (May, 1902), and it was afterwards ascertained, consisted of the same water sampled at different points in the towll. The stoppers of the bottles were for the most part old ones, suggestive of a variety of odors, and, improperly, were sealed in with wax. While it was considered alnıst a waste of time to do anything with these samples, still it was thought that they might serve for a preliminary analysis, to furnish an idea as to the general character of the water. 
RURAL WATER SUPPLY.

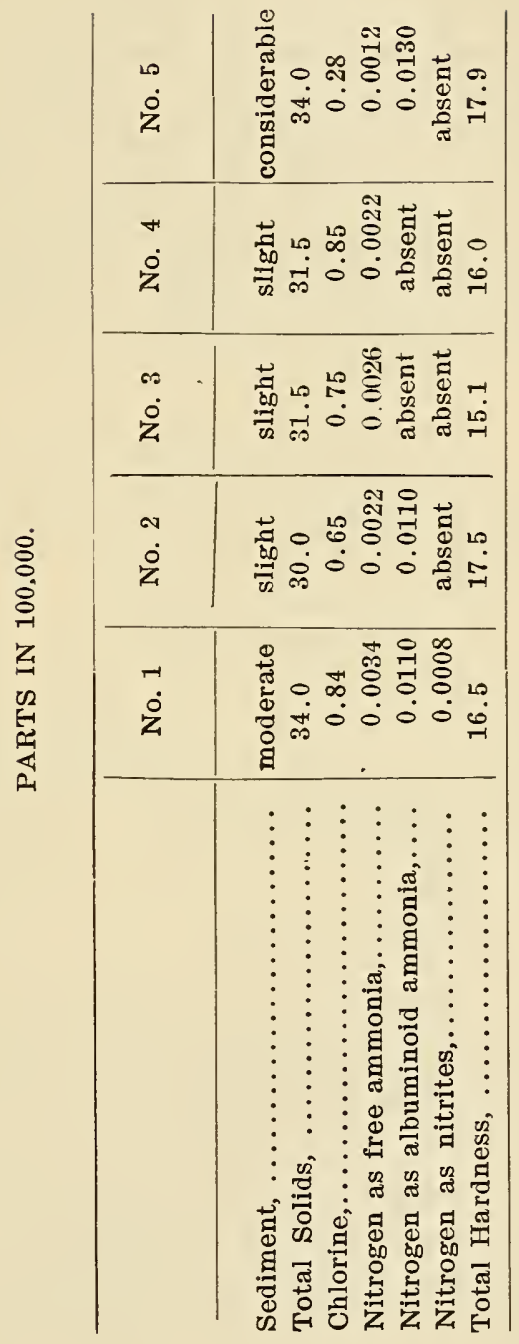


While moderate variations in the amounts of the various forms of nitrogen in the same water, sampled at different points may be expected, it is difficult to explain the differences shown above in the figures for chlorine, which latter, unlike the nitrogen, represents a fixed, stable body. In view of these differences: and the possibility that they may have been caused in part. at least, by errors in sampling. no definite opinion could be rendered without further work upon samples taken in person, and a full knowledge of local circumstances. Unfortunately, nothing further was learned of the matter.

\section{KANAWHA RIVER WATER.}

'The analysis of a sample of Kanawha River water, taken at Charleston, in April, 1900, was as follows:

\section{PARTS IN 100,000 .}

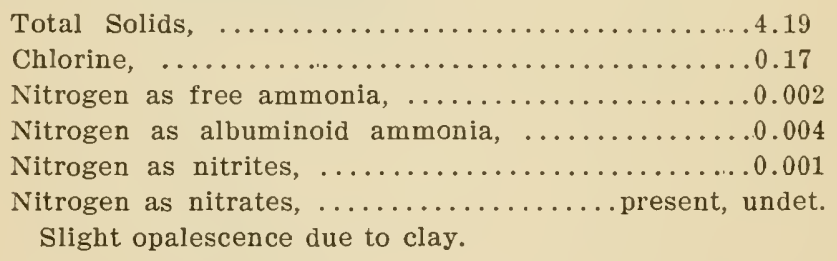

No information accompanied this sample, though it was assumed to be the regular city supply, as drawn from the spigot. 'The only unfavorable indication in the above analysis is the figure for nitrites. The latter, however, would be of itself quite sufficient to subject the water to grave suspicion; but as this constituent may easily have been an accidental one as the result of improper sampling or the use of an insufficiently clean vessel, it would be improper to pass judgment without further analysis. 


\section{WATER FROM DRILLED WELL AT MORGANTOWN.}

Following are two analyses of water from a drilled well at the Morgantown Ice Plant. This well, which is 150 feet deep and cased with common iron pipe, is located ten feet from the building. A steam pump is employed. and the water, which is exceptionably cold, is used for condensing the steam in the process of obtaining the distilled water from which the ice is manufactured. Sample No. 1 was sent into the Station, sample No. 2 being taken personally. Both were obtained directly from the pump, outside the building, before the water had entered the storage tank.

PARTS IN 100,000 .

\begin{tabular}{|c|c|c|}
\hline & No. 1 & No 2 \\
\hline 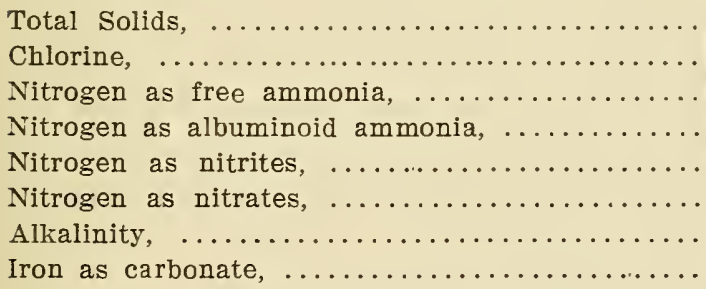 & $\begin{array}{l}26.5 \\
1.8 \\
0.0206 \\
\text { absent } \\
\text { absent } \\
\text { absent } \\
19.0 \\
\ldots \ldots \ldots\end{array}$ & $\begin{array}{l}1.8 \\
0.0216 \\
\text { absent } \\
\text { absent } \\
\text { absent } \\
19.0 \\
0.66\end{array}$ \\
\hline
\end{tabular}

The point of interest in the above analysis is the somewhat high free ammonia. In the absence of any particulars most chemists would doubtless assume that this ammonia leached into the well from the plant. However, investigation showed that the well is drilled much of the way through rock, that it had been cemented about the top with especial care, and moreover that, except in the extreme case of accident, no trace of the odor of ammonia is at any time detectable about the plant. In addition, the rate of pumping is so rapid that the water is continuously drawn from the well about as fast as it accumulates.

The location of this well, from a sanitary standpoint, is 
such that were it a shallow one, this item alone wonld be surficient to condemn the water. Under the circumstances, however, and in the light of later observations made by the writce on the occurrence of ammonia in deep well waters, the presene? of such in this case is ascribed to the existence of ammoniacal silicates in the argillaceous strata traversed by the water. The source of this ammonia may be found in the nitrates formerl from the decomposition of the vegetable life of a past geologic age, such nitrates probably having undergone subsequent reduc. tion through the ageney of sulphur compounds. Waters of this class, it has been observed, are always alkaline, and nearly always contain sulphuretted hydrogen gas. ${ }^{2}$ Hunt points out the fact that ammonia is a considerable constitrent of the gases emitted by volcanos. He assumes that this body is derived partly by absorption, on the part of argillaceous strata, from the ancient atmosphere to which such strata were once exposed: partly, also, by the action of heat on nitrogenized orgauic matter. 'This theory is analogous to that held by geologists concernine the formation of natural gas and petroleum. 3Phillips has found from one to nearly three per cent. of nitrogen in natural gas: and as is well known, ammonia is an important by-product in the manufacture of artificial gas.

This water occasioned the ice company much troub!e on account of the formation of a thick red shdge of iron, which was rapidly deposited upon the condenser tubes of the distilling outfit. This iron is held in solution by carbonic acid gas and is derived in part, no donbt, from corrosion of the well tubing. Th: gas also gives rise to a certain amount of corrosion of the hot condenser metal. Upon aeration, such gas is expelled and the iron is deposited upon the tubes and upon the bottom of the distributing tank located at the top of the plant. This tank has a galvanized iron lining which has undergone extensive corrosion.

2 "Chemical and Geological Essays."

3 Proceeding Engineering Soc., Western Pennsylvania, 1898. 
In this respect its action represents that of a zinc-iron couple. The latter is sometimes used as a water softener, zinc plates being attached to the inner surfaces of the boiler. Carbonic acis dissolved in the water attacks these plates instead of the iron, the zinc being transformed into a basic carbonate and carried down as a soft sludge along with carbonates of lime, magnesia, or iron that may be present. Very many waters will not bear transmission in zine lined pipes for this reason. The obvious remedy for the trouble caused by this particular water is aeration, whereby carbonic acid gas is removed and the iron rendered insoluble. This might be advantageously effected by forcing the water through a scrubber, containing coke and a little metallic iron or zinc scrap.

\section{WELL AT WES'TON.}

This water is also an instance of a deeply seated water carrying high ammonia. The samples came from a newly drilled well 850 feet deep, located upon a hillside high above the town of Weston, and altogether removed from any possibility of surface contamination. This well was put down with a view of securing a better and more adequate supply for the State Hospital for Insane. Sample No. 2 was carefully taken according to instructions, after twelve hours of constant bailing.

PARTS IN 100,000.

\begin{tabular}{|c|c|c|}
\hline & No. 1 & No. 2 \\
\hline Total Solids, (unfiltered) ......... & 201.40 & 216.60 \\
\hline Total Solids, (filtered) $\ldots \ldots \ldots \ldots \ldots \ldots$ & $\ldots \ldots \ldots$ & 200.00 \\
\hline 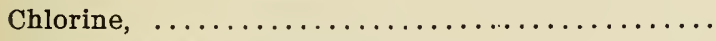 & 75.00 & 75.00 \\
\hline Nitrogen as free ammonia, $\ldots \ldots \ldots \ldots \ldots \ldots$ & 0.066 & 0.078 \\
\hline Nitrogen as albuminoid ammonia, ........... & 0.033 & 0.005 \\
\hline Nitrogen as nitrites, $\ldots \ldots \ldots \ldots \ldots \ldots \ldots$ & 0.004 & trace \\
\hline Nitrogen as nitrates, $\ldots \ldots \ldots \ldots \ldots \ldots \ldots$ & absent & absent \\
\hline 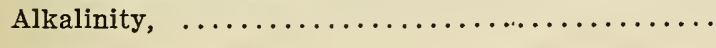 & $\cdots \cdots \cdots$ & 66.00 \\
\hline
\end{tabular}


MINERAL COMPOSITION OF NO. 2 FLLTERED FROM IRON SLUDGE.

Grains Per U. S. Gallon.

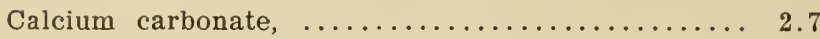

Magnesium carbonate, .................. 1.5

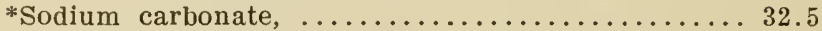

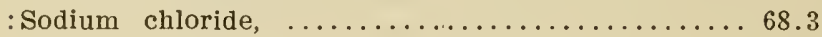

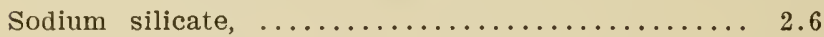

Iron and alumina, ........................ 0.1

Potassium sulphate, ........... (trace-not estimated)

Lithia, bromine, and iodine, ......(trace-not estimated)

*Approximately equivalent to $3 / 4$ 1b. of bicarbonate of soda in 100 gallons.

Approximately $1 \mathrm{jb}$. common salt in 100 gallons.

This water had a disagreeable alkaline saline taste, was of a blackish color, and smelled strongly of sulphuretted hydrogen gas when first drawn, though both color and odor very quickly disappeared. and a sludge of iron hydrate was deposited. Being far too highly charged with mineral matter to be of service for domestic purposes, the well was bored deeper, with the result that a valuable supply of natural gas was obtained.

\section{ARTESIAN WELL AT WILSONBURG.}

This is a flowing well, one hundred and twenty-six feet deep, the water of which is bottled and finds an extensive local sale. A mineral analysis will be given in a subsequent bulletin. A sanitary examination of this water was satisfactory in all respects except the free ammonia, the proportion of which, as in the preceeding case, being large. The surroundings are such, however, that surface pollution would seem to be out of the question, so that this is doubtless another example of a water carrying nitrogen compounds derived from deep strata.

\section{WATER SUPPLY OF ROMNEY.}

A sample of the above was forwarded to the Station for analysis by Dr. G. H. Thomas, during October, 1899. The supply consists of a mountain stream fed by springs. While noth- 


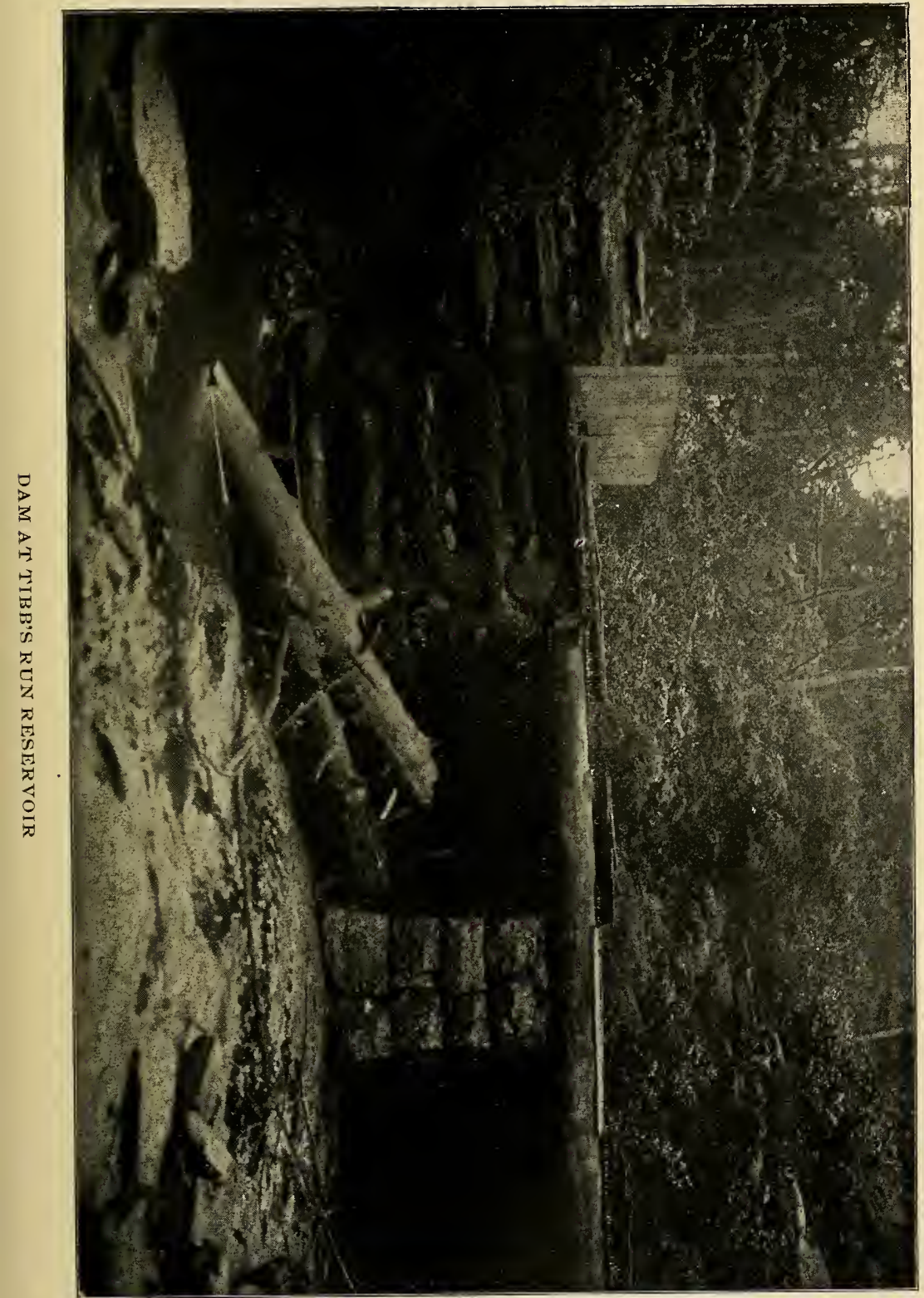



ing very definite was learned with regard to the possibilities of sewage contamination, it is understood that there are a number of dwellings along the banks of the stream and presumably the presence of accompanying sink drains or out-houses may render quite possible the infiltration or direct entrance of sewage at certain points. Several cases of typhoid fever had occurred along the stream and it was supposed that such originated in the use of this water. The following chemical analysis fails to indicate anything at all suspicious, however.

PARTS IN 100,000 .

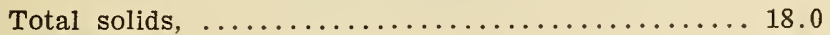

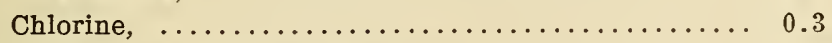

Nitrogen as free ammonia, ............... 0.002

Nitrogen as albuminoid ammonia, ........... 0.006

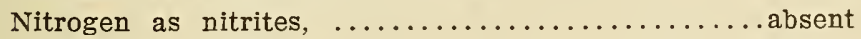

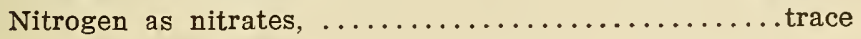

While the albuminoid ammonia is not at all excessive, yet the normal figure is doubtless augmented by the products in the stream of decaying leaves and similar material, always abundant at this season of the year. Neither is the solid content at all $a b$ normal, considering the source and geological formation of the section. If one were to base a decision upon the results of a solitary analysis, he would be justified in pronouncing this water pure. Nevertheless, a determination of solids and chlorine in a sample taken higher up along the stream might have revealed some significant differences.

\section{ARTESIAN WELL AT FAIRMONT.}

The above well, recently drilled upon the property of T. W. Fleming, Esq., is 205 feet deep and affords another illustration of a pure alkaline water containing much free ammonia. This water shows no albuminoid ammonia, nitrites, nor nitrates, but carries 0.042 parts of nitrogen in the form of free ammonia. It is highly alkaline, containing the equivalent of 12 ounces of bicarbonate of soda in each 100 gallons. 


\section{WELL AT ADAMSTON.}

During May, 1903, samples were received from two wells located at Adamston, a point near Clarksburg. Both wells are within a few feet of a large double house, formerly tenanted by the families of miners. No. 1 is convenient to a large porch upon which it was customary to do washings and from which, it was represented, not only wash water but house slops of all kinds were thrown. These collected in a slight depression in the sandy soil, where, penetrating to the clay sub-stratum, they were undoubtedly conveyed directly into the well. Two years previous to the above date several cases of typhoid fever occurred among the occupants, from which four deaths resulted. Well No. 1 was then condemned and No. 2 was constructed at a point on the other side of the house and at a somewhat higher level. During the past six months the house had been untenanted, but is now again occupied, and at the date when the samples were taken. from ten to fifteen persons were using water from well No. 1, it being represented that no surface drainage now reaches it. Analyses of both waters follow. (Wells each about 75 feet deep, loose walled for 26 feet).

\section{PARTS IN 100,000 .}

\begin{tabular}{|c|c|c|}
\hline & No. 1 & No. 2 \\
\hline Total solids, & 44.0 & 45.0 \\
\hline Chlorine, $\ldots \ldots \ldots \ldots \ldots \ldots \ldots \ldots$ & 2.7 & 1.1 \\
\hline 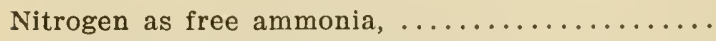 & 0.0028 & 0.0014 \\
\hline Nitrogen as albuminoid ammonia, ........ & trace & absent \\
\hline 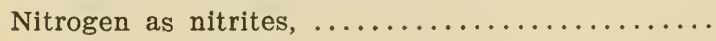 & 0.0004 & trace \\
\hline 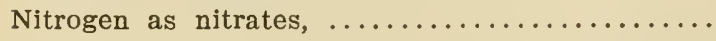 & 0.80 & 0.40 \\
\hline
\end{tabular}

No. 1 was somewhat opalescent in appearance and carrier some sediment, mainly iron. No. 2 was elear and without sediment. In these two analyses a rather unusual opportunity is 
presented for observing differences in the amounts of certain constituents in two similar waters, from near by sources, which differences, in this connection, can be indicative of nothing other than pollution in the case of No. 1. The analysis shows conclusively that the latter water, while previously contaminated, now carries but a relatively small proportion of unoxidized organic matter; that this oxidation, however, is not as yet fully com. plete; and that, therefore. in the writer's opinion the use of this water is still attended by risk.

\section{SPRING WATER CONTAINING NITRATES.}

This Station is sometimes called upon to examine waters with a view to determining their medicinal value. In several cases, spring waters have been received which were high in content of nitrates and chlorine, although very free from organic matter or other evidences of pollution. Concerning surh the following instance is especially deserving of mention. The sample was sent in by a partv who expressed his intention of putting the water upon the market for table use.

Information concerning the local surroundings revealed the following facts : The spring is located in a hillside orchard, about 100 feet from the summit of the hill. The only chance for pollution was represented as being an outhouse which stood about 90 feet avove the spring, but which was, however, provided with a tight box receptacle, su that no trouble from this source was anticipated. Further investigation, nowever, elicited the fact that the box had but recently replaced the use of an uncemented pit, and moreover, that the box itself at the time the sample was taken, was found to be in a leaky condition. At the top of the hill is a large level area, which had been very heavily fertilizerl with stable manure during the past few seasons. 
Following is the sanitary analysis:

PARTS IN 100,000 .

Clear and odorless.

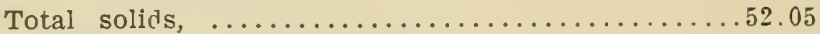

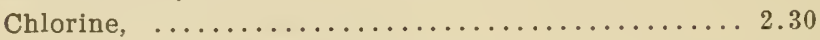

Nitrogen as free ammonia, .................trace

Nitrogen as albuminoid ammonia, ..............bsent

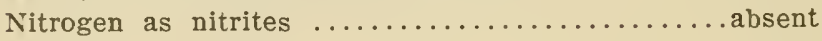

Nitrogen as nitrates, $\ldots \ldots \ldots \ldots \ldots \ldots \ldots \ldots \ldots \ldots{ }^{* 2.00}$

*Equivalent to 7 grains per gallon of nitrate of soda.

The analysis shows beyond question that the spring receives to a very considerable extent, drainage from the closet or cultivated field, or both. In spite of the fact that subsequent percolation through the soil has freed the water of most of its organie matter and that, in its present condition, it might therefore perhaps be considered as being reasonably pure and usable. yet a favorable certificate of analysis was unhesitatingly denied the applicant on the ground that the general use of such waters is al. ways attended by risk. Sanitarians now recognize the fact that oxidation of the organic matter in a water through soil percolation, by no means necessarily involves the accompanying complete destruction of all disease germs that may be present. And as the advent on a large farm employing much help, of unsus. pected, so-called "walking" cases of typhoid fever might occul' at any time, the danger is always imminent of such water becoming an active agent in the distribution of disease. The water of hundreds of wells in daily use in our villages and larger towns is of the same general character as the above. Such are unsafe, not because the water is necessarily impure, but because the agencies which are now effecting purification are uncertain of action, and the admission of disease germs is possible at any time. 


\section{BLACKSVILLE WELL.}

The following is an instance of a moderately deep, drilled well. the water of which, used by many people for drinking purposes, was plainly contaminated by surface drainage. This well, which is situated on a hillside near the local hotel, is 90 feet deep and lined with tile "to the rock." The distance to "the nearest cess-pool, privy, or stable" was given as 15 feet above. The water, which was slightly opalescent and possessed a pronounced earthy, vegetable odor, gave the following data:

\section{PARTS IN 100,000 .}

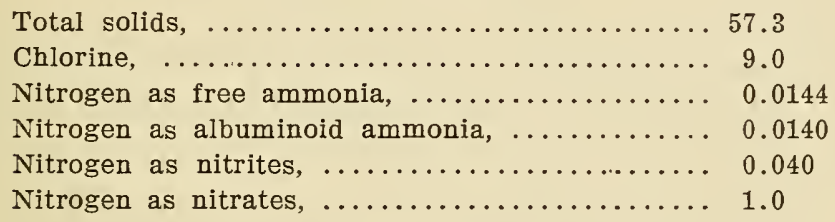

Condemnation of this water was based upon the above analysis, taken in connection with the information concerning local surroundings. 


\section{Instructions for Sampling Water.}

Parties residing within the State desiring to have drinking water analyzed should first make application to the Director of the Station, at the same time stating their reasons for wishing the analysis. Whereupon, if the work of the chemical department permits, blanks and any necessary sample bottles will be forwarded, and analysis and opinion regarding quality furnished free of charge.

Procure a clean glass bottle or demijohn of at least two quarts capacity. This will be furnished by the Station if desired. A jug should not be used. Rinse the thoroughly cleaned vessel sereral times with the water to be examined, fill, and stopper tightly with a new cork that has previously been boiled in clean water for a few minutes and then rinsed with the water to be sampled. As a protection to the mouth of the bottle a piece of new, clean, linen or cotton cloth should be tied nver the neck; handling of the latter should be carefully avoided. Use no sealing wax or paraffine.

Crate the bottle, mark sender's name and address upon the outside of the package, and ship, express charges prepaid, to the Fixperiment Station, at Morgantown. Parties sending samples during the winter should bear in mind the risk of freezing and bursting of bottles.

At the same time that the sample is sent, the blank shoul $r_{1}$ be filed out and returned by mail. The information therein contained is indispensable in forming judgment of quality. No report will be made unless the sample is taken according to instructions and full information given. In the case of public supplies, a preliminary consultation and inspection will be necessary. 


\section{A Study of the Monongahela River Supply at Morgantown.}

The source of Morgantown's first public water supply was a small stream fed by mountain springs. The impounding reservoir was located on Tibbs' Run, in a rocky, isolated spot, surrounded by dense forest growth. From the reservoir the water was conducted through log pipes to the storage tanks at Morgantown.

Analysis of a sample of this water, taken at the reservoir June 27, 1903, shows it to be of a high degree of purity.

WATER FROM TIBB'S RUN RESERVOIR.

PARTS IN 100,000.

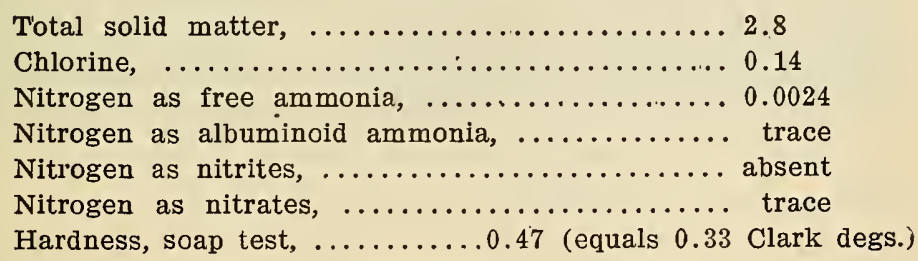

A remarkable feature of this water is its low content of mineral matter, thus indicating the insoluble nature of the rocks through which it has travelled. In this respect, it is very similar to the water of a popular spring located not a great distanec away from the above, at Sturgisson, on the Morgantown \& Kingwood Rail Road. This spring issues from the base of a hill near by the present quarry of the Deckers Creek Stone and Sand Co. 
Although limestone is said to occur in abundance but a few rods away, yet it is evident that this water, throughout its travels has come in contact with nothing more soluble than the sand rock from which it issues.

\section{STURGISSON SPRING WATER.}

PARTS IN 100,000 .

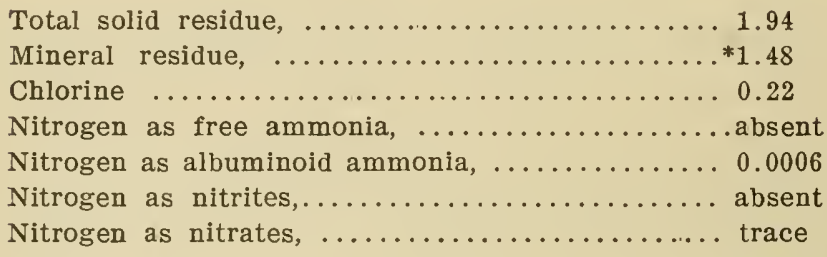

${ }^{*}$ Equivalent to 0.84 grains per gallon of mineral matter.

This spring is said to deliver a four-inch stream during most periods of the year-never less than three inches at any time. The accompanying photograph was made July 16 . Temperature of the water, taken at that time, was found to be 56 degrees Fhr. A gas analysis made at the spring, showed but 0.84 cu. in. of carbonic acid gas per gallon, although the presence of considerable nitrogen and oxygen was observed.

The water of another spring, located five miles from Morgantown, between Dellslow and Ices' Ferry, is in the same class with the preceeding. This water, however, contains a little more mineral matter (lime) and is not quite so free from organic matter, although the latter is doubtless of humic origin.

It is interesting to compare the content of total solids amr lime of these three waters with that of the Martinsburg spring, page 178. It appears to the writer that the former are representatives of a class, which, while common in the older granitic formations, is somewhat unusual in West Virginia, a state abounding in highly mineralized springs. The course of such waters as 


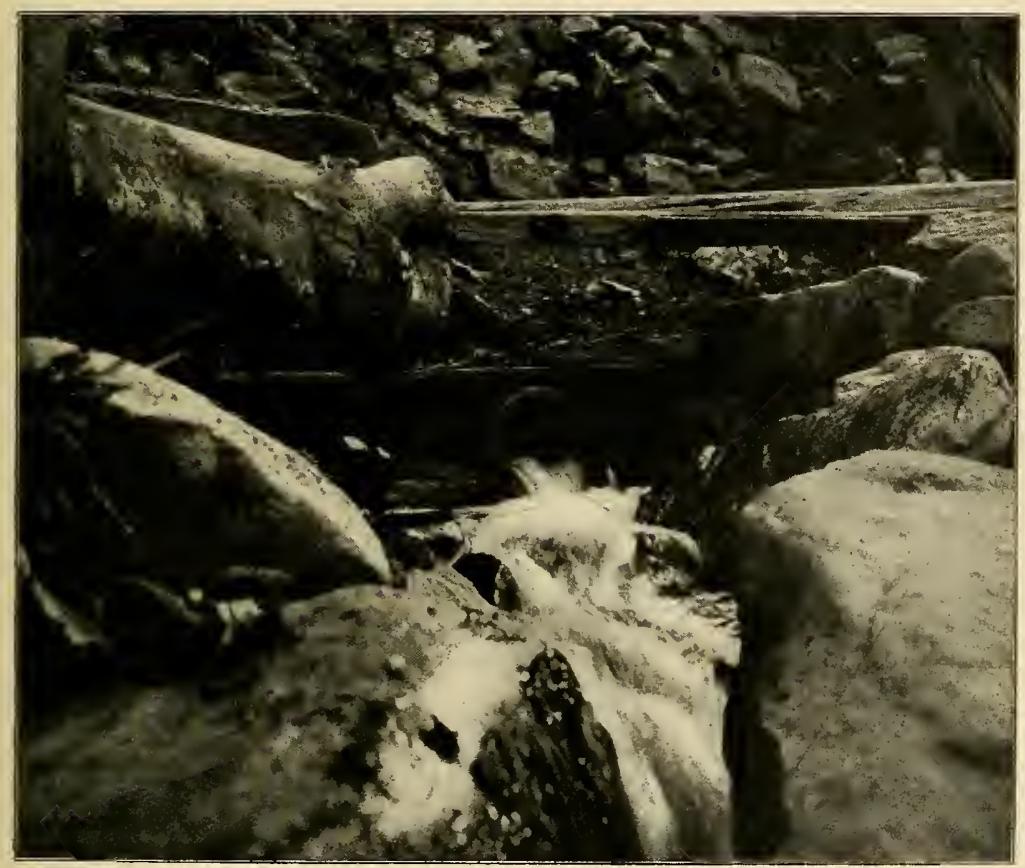

A MOUNTAIN SPRING IN MID SUMMER 

the above is mainly confined to veins of sandstone or quartzite, hence the name "freestone," sometimes applied to them.

With Morgantown's rapid industrial growth, the Tibbs' Run supply soon became inadequate and is now practically abandoned, although water still traverses the mains to the storage tanks at East Morgantown, and is subsequently mixed with the river supply. The Sturgisson Spring, though a public "supply" only in a very limited sense, is mentioned in this connection because of its popularity with Morgantown citizens, and its increasing local use as a table water.

The foregoing are fair specimens of the numerous springs and runs scattered throughout the Cheat Mountain section. Many of these are said to be of large size, and the practicability has been urged of the continuation of their use by the city. While such would undoubtedly mean one of the finest supplies in the world, in point of quality, yet it is probable that the difficulties in the way of concentration for the large demands of the present and near future, would not prove easily surmountable.

During the past five or six years the Monongahela River has been used as the main source of supply. At first the water was pumped directly into the mains without any attempt at purification or removal of the sediment, with the result that, during periods of rainy weather, the supply as drawn from the tap, presented an appearance ranging from light yellow to chocolate brown. Later, the South Park reservoir was constructed and a system of mechanical filtration installed at the pumping plant. The latter is now undergoing extensive enlargement and improvement, the filtration capacity being increased from $1,000,000$ to 2,000,000 gallons daily.

The Monongahela River, in common with others of its class, is subject to rapid and pronounced variations, both in volume and the character of the water. A few hours of heavy rain in the mountain sections are sufficient to raise the level several feet, while autumn rains and spring freshets increase the volume far beyond the normal. A rapid volume increase is always attended 
by a marked turbidity of the water, due to the enormous quantities of finely divided clay particles washed into the river.

Below are indicated variations in the quantities of suspenderl matter:

Parts in $100,000$.

Solids-river.

October $6,1900 \ldots \ldots \ldots \ldots .14 .4$

November $27,1900 \ldots \ldots \ldots 30.5$

August 7, $1902 \ldots \ldots \ldots \ldots \ldots$

February 11, $1903 \ldots \ldots \ldots \ldots \ldots$

February 16, $1903 \ldots \ldots \ldots \ldots \ldots$

June $9,1903 \ldots \ldots \ldots \ldots \ldots \ldots 46.8$

June $10,1903 \ldots \ldots \ldots \ldots .14 .0$
Solids-effluent.

10.0

5.2

3.9

5.5

10.2

5.0

5.0
Suspended matter removed by filtration

4.4

25.3

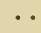

.

$\cdots$

41.8

9.0

Along with the clay and silt vast numbers of bacteria are also carried into the river, thereby increasing the normal bacterial population many fold. In a sample from the intake pipe at the pumping station, taken June 19, after an extended period of fair weather, 300 bacteria per c. c., were counted, while a sample taken June 22, just after a heavy rain, showed 26,000 bacteria per c. c.

Numerous observations show that the bacterial content of all rivers varies with the scason, being the highest in winter and spring and lowest in summer. Thus, Dr. Theobald Smith 4 found in Potomac River Water, bacteria per c. c. as follows:

January, ...3,774 'May, .......1,064 |September, . . 178

February, ..2,536 June, ..... 348 October, .... 75

March, .....1,210 July, ........ 255 ' No,vember, .. 116 April, ......1,521 August, .... 254 |December, ... 967

These numbers are doubtless in fairly constant proportion to the rain-fall, although the action of sunlight as an agent destructive to bacterial life, needs some consideration in this connection. 
The best answer to the usual queries concerning the quality, safety, or probable responsibility of a river supply for the prevalence of typhoid fever in those communities using its water, is in calling the general public's attention to the fact that, whatever the rivers may have been in the days of the pioneer, they are now the sewers of the country; upon them falls the burden of carrying a large part of the waste of a nation to the sea. To be sure, these vast bodies of sewage are very largely diluted by the water of brooks and springs, and in certain sections of the country moderate sized rivers exist, the waters of which may carry but infinitesimally small proportions of the refuse of human existence. Such, however, are not to be found in populated sections, and it may therefore be laid down as a general rule that the water of none of our rivers is entircly "safe" for drinking purposes antil subjected to filtration*.

*It might be argued that, in the case of the Cheat River, this rule does not hold. The Cheat flows through a wild and mountainous section of the country, and throughout the greater part of its course to the Monongahela it drains a sparsely populated water-shed. Local opinion has it that this water is very pure. And unquestionably this was true at one time, but it is not true to day, and with the rapid de. velopment of this section consequent upon its great wealth of coal and timber, the quality of Cheat River water will inevitably continue to deteriorat. A sample of this water, taken August 10, 1903, one mile above Point Marion, besides containing much organic matter, possessed a deep yellow hue, corresponding to a standard color of 0.5. This color is mainly due to the resinous material discharged into the river by the pulp mills at Parsons and Davis. In the process of reduction to pulp, approximately one-half of the original weight of the wood is dissolved. In many localities the discharge of this acid sulphite liquor into streams has been found to cause the destruction of fish, which it does partly by abstracting from the water the dissolved oxygen necessary for respiration, though mainly, however, by giving rise to the formation of a resinous film upon the breathing apparatus of the fish $\%$. According to recent reports from St. George and Rowlesburg, the discharge into the river of mine water, coke washings, tannery waste, sawdust, and pulp liquors, has given rise to a highly contaminated condition of the water at those points.

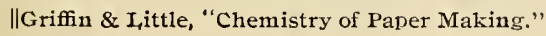


According to Chapin, 5 statistics show that supplies derived from a water-shed having a population of twenty-five or more per square miles are usually open to suspicion, while with a population of fifty or more, such as is commonly the case, the water is nearly always contaminated to such an extent as to render its use without filtration unsafe.

When a stream is used as a means of sewage disposal by towns of considerable size, as is notably the ease with the Monon. gahela, the fitness of its water for drinking purposes becomes still more questionable, regardless of the distance which may intervene between the sewer outlet and the proposed point of supply. Unquestionably very extensive self-purification almost always occurs during the course of a few miles flow. It has been observed ${ }^{6}$ that the total number of bacteria in Isar River water, twelve miles below Munich, is less than 50 per cent. of the number found just below the sewer outlet of that city. Many other observations are on record going to show that, in from four to twenty miles flow. a river may become freed not only of a large proportion of its bacteria, but also of its organic matter, oxidation and removal of the latter frequently being very extensive. This has been found to be especially true of the Monongahela in its course between Fairmont and Morgantown.

Contrary to the usual belief this purification takes place more rapidly in sluggish, rather than in rapidly flowing streams, the explanation being that, in the former case, the conditions for sedimentation and the accompanying elimination of bacteria are more favorable. This principle has extensive application in connection with the storage of waters in reservoirs preliminary to filtration or the delivery to service reservoirs. According to

5 Ohio Sanitary Bulletin No. 7.

6 Hyg. Rund. 1898, VIII, 161. 
7 Fuertes, twenty-four hours sedimentation means the removal, on an average, of $80-90$ per cent. of both sediment and bacteria. 8That a large percentage of pathogenic bacteria are also removed is shown by the low typhoid death rate of towns using storage reservoirs as compared with other towns not having such, but using water from the same original sources.

The results of modern investigation are not in accord with the almost universal idea that aeration is a great factor in the purification of water. Turneau \& Russell ${ }^{9}$ allude to the fact that numerous experiments on the effect of oxygen and motion have usually failed to show any determinable improvement, anrl mention that Leeds failed to find any difference in Niagara River water above and below the Falls. They conclude that sedimentation and dilution are, by far, the most important agents. Other recent writers deny that aeration plays any role in the oxidation of the nitrogen of organic matter. Previous to the introduction of the lock system between Morgantown and Fairmont, there was shoal water at several points, at which places it has seemed probable that the action of air and sunlight combined, must have had some influence in the production of th: comparatively large proportion of nitrates occuring in the water. Whether the latter will show any deterioration as a result of the completion of the lock system is a question of some slight interest, though it would doubtless prove one difficult or impossible to answer, in view of the constantly increasing pollution to which the river is subjected.

Can the germs of typhoid fever or other diseases survive in the water for the twenty-five miles flow between Fairmont and Morgantown? Concluding from observations made at other

\footnotetext{
7 "Water Filtration Works."

8 Ohio Sanitary Bulletin No. 7.

9 "Public Water Supplies."
} 
places with like conditions, the answer is a decided affirmative. For not only is it certain that they can thus survive, but it is exceeclingly probable that they do. There is ample proof that the high typhoid mortality of the city of Lawrence, Mass., previous to the introduction of filtration, was directly chargeable to Lowell sewage entering the Merrimac river twenty-five miles above. 10Mason instances the fact that, although twenty-six miles and the high Cohoes Falls intervene between Schenectady and Albany, N. Y., Schenectady's sewage, borne by the Mohawk river, was long responsible for fever at Albany.

As a result of a recent study of the Sudbury (Mass.) river, Winslow, Woodman, and Hanson conclude11 that "under certain conditions, bacteria, and even intestinal bacteria, may persist in a stream after self-purification from organic material has been effected; and that they may be found even in a very sluggish stream (a favorable condition for purification), at a distance of ten miles below their point of entrance." Chester mentions 12 an ontbreak of typhoid fever in Wilmington, Del., in 1899, in which thirty cases were traced to the use of water from a certain well. This water gave an excellent chemical analysis and showed but thirty bacteria per c. c.; yet germs analagous to the colon bacillus were repeatedly isolated by the writer, who concludes that such results are but additional evidence of the fact that "a water may be pure from a chemical and general bacteriological standpoint and yet contain a small amount of faecal matter sufficient to make it decidedly dangerous to health." This opinion is sustained by Hammerl,13 who asserts that pathogenic bacteria may persist in a water after it has become impossible to detect pollution in the latter by the regular methods.

10 "Water Supply."

11 Technology Quarterly; 15, 105-126.

12 Report, 1900, Delaware Experiment Station.

13 Hyg. Rund. 1897, VII, 529. 
RURAL WATER SUPPLY.

\section{CHEMICAL EXAMINATION.}

The following chemical analyses, made during the past three years, of the Monongahela River water at Morgantown, serve to indicate the general character of the water. 


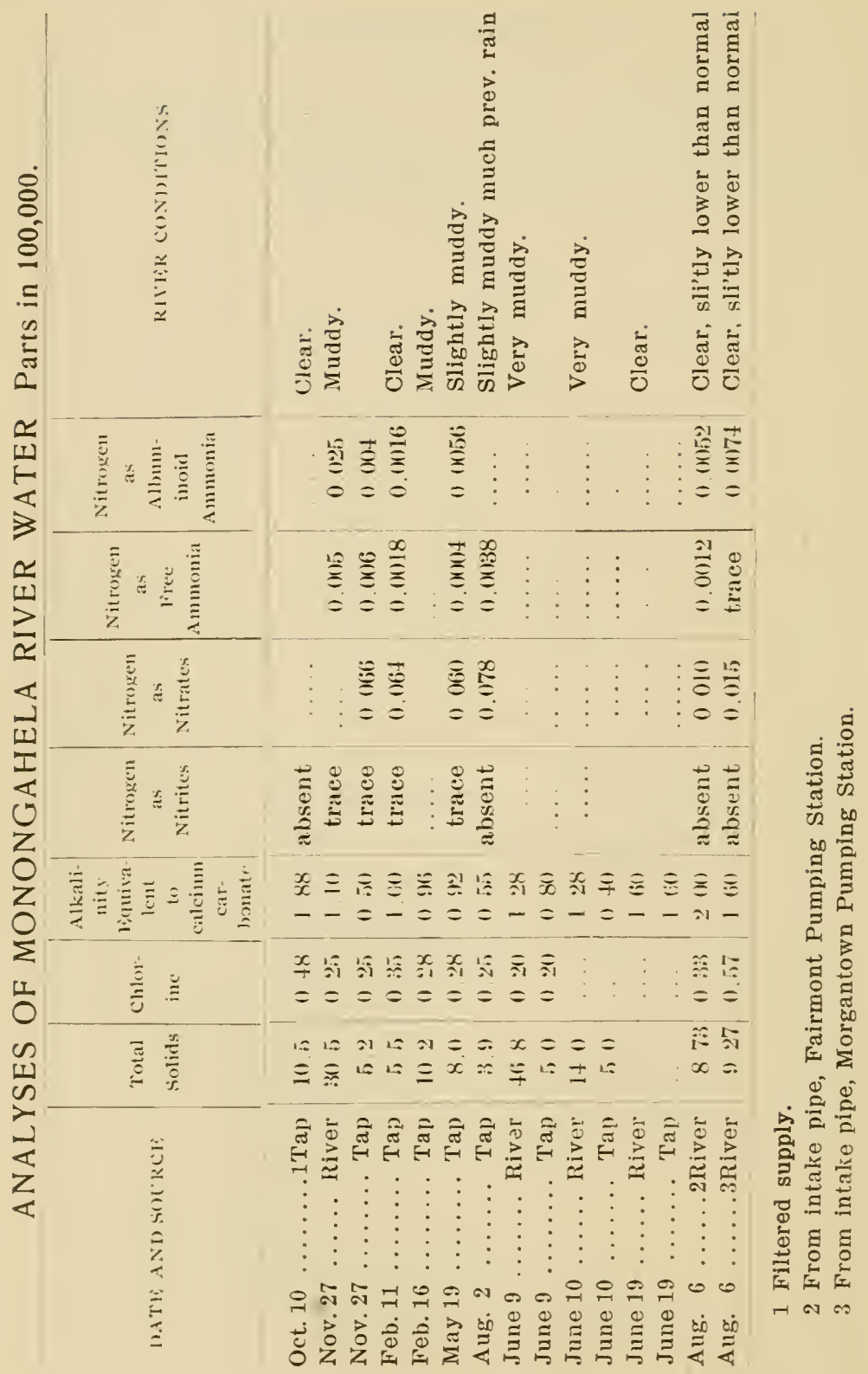


The figures for free and albuminoid ammonia on the tap (filtered) water, it will be observed, are uniformly low; the chlorine, total solid residue, and the alkalinity of both river and tap samples vary greatly. The solid content is dependent on the nature of the season, whether wet or dry, on immediate weather conditions, and, in the case of the filtered water, on the varying working qualities of the filters. The occasional marked reduction in the alkalinity of the filtered water is. of course, due to the use of coagulant in connection with filtration. At periods of heavy rains or floods, the raw water alkalinity is usually much reduced. The water frequently gives a faint test for nitrites, though this seems to be rather more pronounced during the winter than during the summer months.

A comparison of the chlorine in the samples taken August 6, 1903, at Fairmont and Morgantown, respectively, is instructive. The increase in the amount of chlorine at the latter point is wholly due to the entrance of sewage above.

As a whole the analyses uniformly indicate that the filtered water contains but very little nitrogenous organic matter, oxidation and removal of the latter during the course of flow being very extensive.

An estimation of the mineral constituents, made on the samples of August 6, from the intakes at the Fairmont and Morgantown pumping stations, gave the following results: 
GRAINS PER GALLON.

\begin{tabular}{|c|c|c|}
\hline & FAIRMONT. & MORGANTOWN \\
\hline $\begin{array}{l}\text { Turbidity, } \ldots \ldots \ldots \ldots \ldots \\
\text { Jediment, } \ldots \ldots \ldots \ldots \ldots \\
\text { Sodium chloride, } \ldots \ldots \ldots \ldots \\
\text { Sodium sulphate, } \ldots \ldots \ldots \ldots \\
\text { Calcium sulphate, } \ldots \ldots \ldots \ldots \\
\text { Calcium carbonate, } \ldots \ldots \ldots \ldots \\
\text { Magnesium carbonate, } \ldots \ldots \ldots \\
\text { Iron oxide and alumina } \\
\text { mainly from sediment, } \ldots \\
\text { Silica, from sediment, ...... }\end{array}$ & $\begin{array}{c}\text { Moderate opales'ce } \\
\text { very slight. } \\
0.31 \\
0.36 \\
1.95 \\
0.50 \\
0.70 \\
0.09 \\
0.67 \\
4.58\end{array}$ & $\begin{array}{c}\text { very sl't opales'nce } \\
\text { very slight. } \\
0.55 \\
0.37 \\
2.64 \\
0.10 \\
0.70 \\
0.06 \\
0.50 \\
\overline{4.92}\end{array}$ \\
\hline
\end{tabular}

In addition to the larger proportion of common salt in the Morgantown sample, indicative of pollution, we notice a decrease in the amount of lime carbonate, attended by an increase in the amount of sulphate. The proportion of sulphate in both eases is considerable and probably arises to a certain extent from the action of the sulphuric acid in the water from the mines and coke works in neutralizing the lime carhonate originally present.

Although the quantity of scale forming ingredients in Monongahela water at this point, as compared with that in many waters, is not large, still it is sufficient to cause some trouble in connection with its use in steam boilers, unless softener is used. According to the above analysis, about three-fourths of a pound of soda crystals per 1000 gallons, would be necessary to decompose the lime sulphate present. With a higher stage of water, less soda would be required.

\section{BACTERIOLOGICAL EXAMINATION.}

Except for a few counts for total numbers, this work has been limited to tests for the presence of the colon bacillus. The results, however, are conclusive, as in every case except one, 
bacilli analogous to the colon germ were identified in the water. The sample which failed to show this germ was taken at a period of rainy weather, when coagulant was being freely used in connection with filtration.

For the total number of bacteria per c. c. from 1-10 to 1 c.e. of the water was grown on agar agar of standard neutrality for 96 hours, at about $22^{\circ} \mathrm{C}$. The use of a gelatine culture medium was attempted, but this was found to invariably become badly liquified at the end of 48 hours.

January 23, 1903, samples taken from the laboratory tap showed 195 and 210 bacteria per c. c. In another sample taken from the tap February 5th, 594 colonies were counted. June 19th, a sample taken from the runway of the filter tank at the pumping station showed 100 colonies per c. c.; while a sample taken from the exit of the intake (raw water) pipe the same date, contained 300. The latter figures followed an extended period of fair weather. Samples of river and filtered water, taken June 22nd, after prolonged rains, showed 26,000 and 480 bacteria per c. c., respectively. These figures would correspond to a removal by filtration of 98.1 per cent. of the total number, coagulant, of course, being used at this time.

It should be observed, however, that beyond affording us some idea regarding the bacterial population, estimation of th: total number of the bacteria in a water is not a determination of very much diagnostic value. For, just as a wholesome milk may contain bacteria by the thousand and cheese contain them by the million, so surface waters everywhere, as well as those of springs and even deep artesian wells, carry many harmless germs. In connection with filter control, however, bacterial "counts" are of the greatest practical value. In the case of filtered supplies it has long been customary to fix a maximum number of bacteria per c. c. and to assume imperfect filtration whenever this number is much exceeded. Thus, the maximum adhered to by most English and German cities is 100. The latter is also the usual 
specification made by the mechanical filter companies for the operation of their filters.

Concerning the detection of the typhoid bacillus in pollutel river water. all that need be said here is that such is not ordinarily attempted by bacteriologists who are specialists in the matter of water supply. In spite of the logic of such a method to the minds of most individuals and notwithstanding the amount of work done in this direction, up to the present date there is no certain means by which the typhoid bacillus can be isolated from the swarms of normal water bacteria and other saprophytes ordinarily present in a polluted water. For a discussion of this matter and of the application of the colon method in this connection the reader is referred to the works of any of the modern authorities on the subject.

The principle of the colon method is based upon the fact that Bacillus coli communis is a normal inhabitant of the human intestinal tract. and is therefore the specific germ of sewage. In all polluted waters they are always present in much larger numbers than typhoid germs. and are also more resistant than the latter, to opposing agencies. Consequently any water which fails to show the presence of the colon bacillus may be assumed as being typhoid free, and while the rererse is not necessarily true, still the presence of the colon plainly indicates pollution, which indication is sufficient for all purposes.

An important characteristic of the colon bacillus, used in its detection, is its ability to cause fermentation of sugar solutions, with the production of gas and acidity. For this work 25 c. c. of the water were added to $10 \mathrm{c}$. c. of quadruple strength bouillon, $1 \mathrm{c}$. c. of Parietti's solution added, and the bottles placed in the incubator for 24 hours at $38^{\circ}$ C. Parietti's solution is used to check the growth of the common water bacteria. One-half c. c. of the liquid was then added to a Smith's tube containing the glucose solution recommended by the Massachusetts State Board of Health (1 per cent. glucose -|- 1 per cent. peptone), and grown in the incubator for 24 hours at 38 \& $\mathrm{C}$. After inocculating sterilized litmus milk, and Wurtz agar plates, the gas formula was taken. Blank determinations were invariably made. 
On all of the samples examined (save one), gas production was rapid and usually complete in 12-18 hours. Litmus milk cultures invariably coagulated and reddened in 12 hours. The ratio of hydrogen to carbon dioxide varied considerably, being approximately $2 \mid 1$ on the samples examined in January, and $51-2 \mid 1$ on the June samples. While the gas ratio of the true bacillus coli communis was formerly fixed at $\mathrm{H}: \mathrm{CO}_{2} \mid 2: 1$, many recent observers have found marked variations from this ratio, and it is now considered that the latter is largely dependent upon the individuality of the germ and its environment.

As has previously been pointed out, all rivers carry many more bacteria during the winter months than during the summer, and it is unquestionably during the former season that the water attains its most dangerous condition. The suspended activities of the normal bacteria of both the water and soil, as well as the frozen condition of the latter, inevitably mean an increase in the number of parasitic and infectious bacteria washed into the river during the winter, while the higher stage of water and more rapid current do not permit of the same degree of sedimentation and purification that takes place during the summer months. During the latter season the extensive shallows in the river, notably such as exist at Little Falls, entail very material bacterial purification of the water, mainly doubtless, through the largely increased possibilities for the action of sunlight.

\section{FILTRATION.}

Simple sedimentation, and filtration through sand, either with or without preliminary sedimentation, are the two methods in use for purifying municipal supplies. In addition to these, the substitution of artificial stone for the sand, also purification by electrically generated ozone, are methods now receiving soms attention, although it is improbable that either will prove of extensive application in the case of our turbid river waters.

The mechanical system is the form of sand filtration in use 
at Morgantown. This system differs from the older method in that the water passes the sand at a much more rapid rate, the latter being from 80 to 150 million gallons per acre per twentyfour hours, while in the case of the "slow sand system," so-called, the average rate is but two and one-half million gallons. The efficiency of both systems depends upon the formation of a gelatinous film upon the surface of the sand, through which the bacteria cannot penetrate. When more than the mere removal of turbidity is required, the mechanical system applies the foregoing expedient through the use of a coagulant, the latter producing an efficient film within a few minutes, whereas, that naturally formed by the "slow" system requires several days' time.

The fact that so unpalatable a substance as alum should be added to water in connection with filtration, seems to be the basis for an almost insurmountable prejudice against the system in the minds of many people. However, two things may be emphasized: first, that the "alum" used in connection with filtration is not the alum of the household, but a much more insoluble substance; second. that the latter substance on being introduced into the water, becomes perfectly inert and settles out with the clay, no trace of the soluble compound ever passing the filters.

The chemical reaction involved in comnection with coagulation is as follows :

Alumina sulphate-|-lime carbonate (of the water) $=$ alumina hydrate (insoluble) - -lime sulphate. That is, a transposition occurs, whereby a minute amount of carbonate of lime, contained in the water, is converted into sulphate, while all the alumina is completely precipitated as the insoluble gelatinous hydrate. The latter has both a mechanical and a physical action upon the clay particles, not only dragging them down in the process of settling, but causing such particles to coalesce or flocculate into much larger, compound particles. The settling of such a mass of coagulum involves a very extensive removal of bacteria, and most of those remaining are held back on the filter by the gelatinous sand film. 
It will be seen that this process of coagulation cannot injure the water from a hygienic standpoint; that it does not rob it of "essential salts," as is sometimes claimed. It is true that a small amount of temporal'y hardness is converted into the more objectionable permanent form. Yet, for the benefit of those using steam boilers, it should be stated that the amount of permanent hardness, or ' $h a r d$ scale' ingredients, thus produced, is very slight, as compared with that already present in Monongahela water at Morgantown, as much of the alkalinity has already been neutralized. (See page 202.)

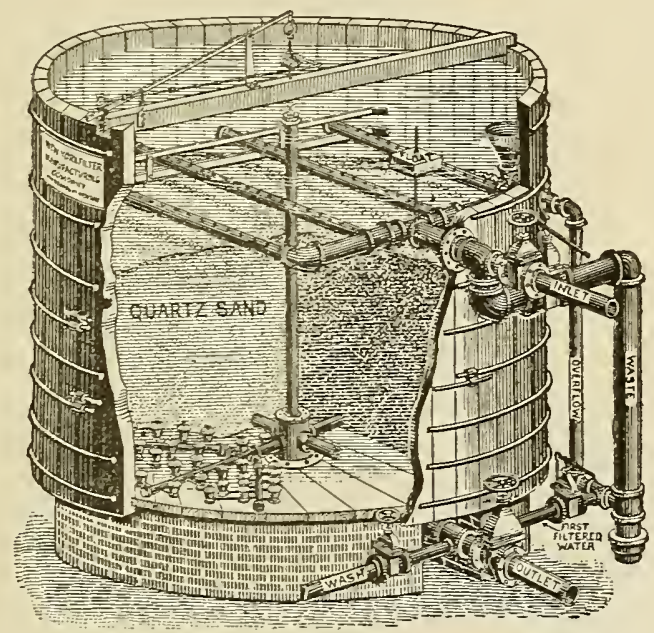

A Mechanical Filter.

The illustration represents the New York Sectional-Wash Filter, in use at the Morgantown filtration works. The same system is employed in this state at Fairmont14, Huntington, and Benwood. Although the pumpage at Morgantown at present amounts to slightly less than 1,000.000 gallons daily, the plant is now being enlarged to 2,000,000 capacity,and, with the completion

14 At the present date Fairmont's supply is not filtered, as the consumption is largely in excess of the present filter capacity. 
of the present improvements, will be superior to any other now in the State.

As represented, these filters are wooden tanks 17 feet in diameter, and 14 feet high, charged with about four feet of sand of 20-40 mesh. The process may be described as follows: After the water has been automatically charged with a minute dose of alum it passes to the settling tank, where it undergoes the same clarifying process that occur's when an egg is used to settle coffee. From thence the nearly elear water flows to the surface of the sand in the filter, and with the "head" secured, passes through rapidly to the collecting strainers upon the bottom of the tank. These strainers gather the now purified water and carry it to the clear water well, from which it is subsequently pumped to the reservoir. The admission of the water and the consequent rate of filtration is regulated and made steady by means of a floar valve.

The washing of the filters, performed twice or more every $2 \frac{1}{t}$ hours, is effected by a reverse eurrent of filtered water. After the accumulation of mud has been washed from the surface of the sand back into the river, the filtered water is allowed to run to waste for some moments until the gelatinous film is once more established.

In connection with the purification of a contaminated river supply by this system, there are three essentials which should be rigidly observed. These are, the use at all times of coagulant, the maintenance of a steady, uniform rate of filtration, and adequate provision for sedimentation of the water at those times when the latter is abnormally turbid.

The fallacy of the idea that coagulation is unnecessary except at times of rains was proved some time ago by certain cities of the Central West, when bacteriologists demonstrated for them that this auxiliary increases the bacterial efficiency from a low rate of $95-99$ per cent. Mazen 15 puts the matter thus: "The suc-

15 "Filtration of Public Water Supplies." 


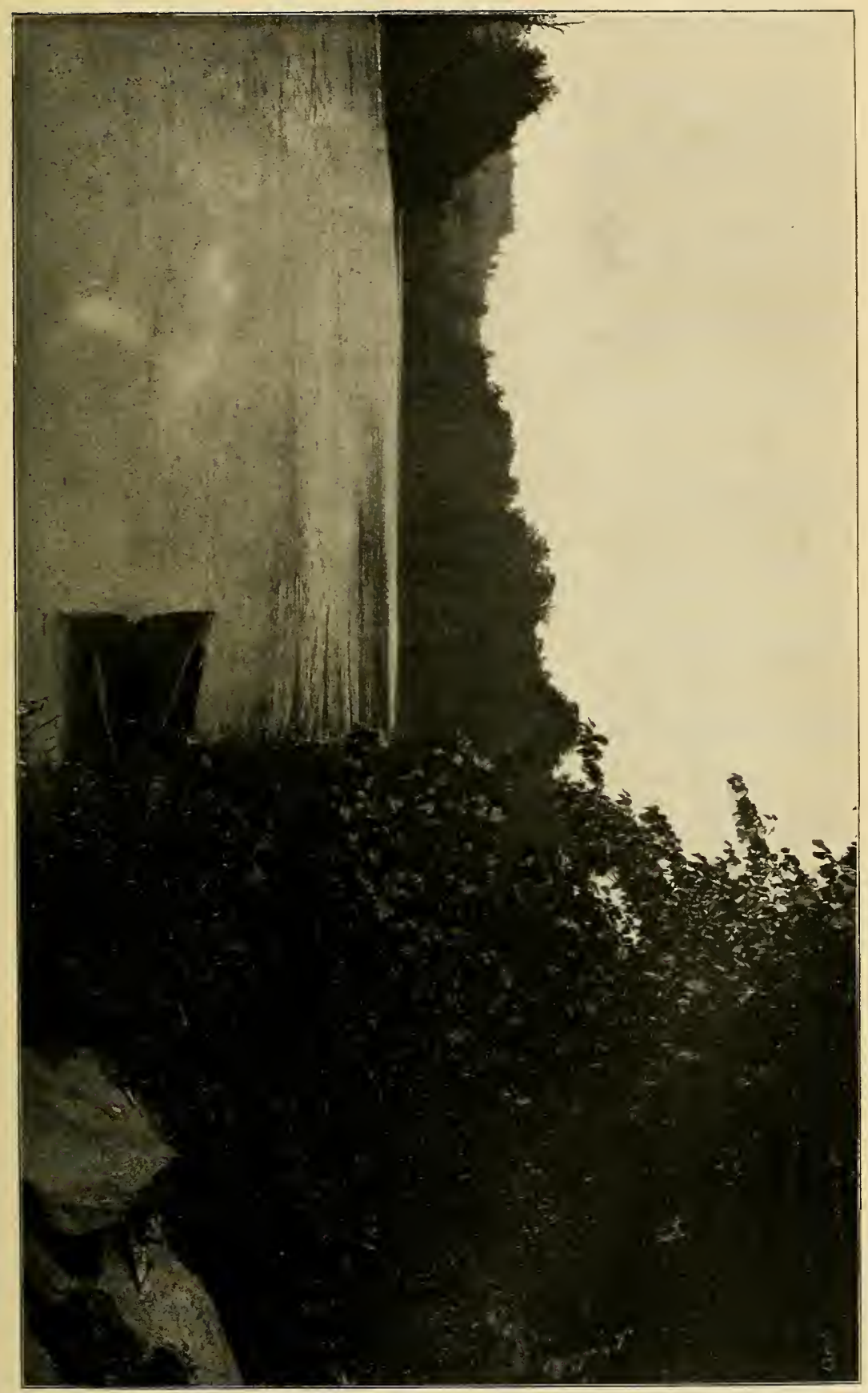



cess of the process, from a sanitary point, depends absolutely upon the alum being applied to all the water and in the proper proportions. - - The failure to apply alum, say, for a few minutes in the middle of the night, means that for a time unpurified water will be delivered."

Basic sulphate of alumina costs from 1c to $2 \mathrm{c}$ per pound. A one-grain treatment per million gallons involves the daily use of 143 pounds of coagulant. In the writer's estimation, the rate for Monongahela river water at Morgantown should not be less than 3-4 grain per gallon at any time and during rains and floods this quantity should be increased.

It is evident that coagulation, properly applied, involves careful management. For its successful conduct occasional chemical and bacteriological examinations are indispensable. So far as the possibility of the introduction of an excess af alum is concerned, however, it should be said that, under normal conditions, the river alkalinity is much in excess of that required to react with and completely decompose the maximum quantity of coagulant that would be used. During extreme flood conditions the use of a small amount of lime water is usually found necessary.

Regarding the bacterial efficiency of the mechanical system as compared with that of the slow sand system, it seems to be the opinion of all water specialists who have given the matter any recent study, that there is now practically no choice between the two methods. The nature and size of the supply and local conditions are the factors which determine their relative adaptability to any particular case. There seems to be no reasonable doubt but that, all things considered, the mechanical system with coagulation is the one best adapted to the use of the smaller cities using Monongahela river or similar water. 


\section{CAUSATION OF TYPHOID EPIDEMICS.}

The following is a summary of the modern views upon the subject. Medical science holds that typhoid fever is a disease spread almost exclusively by food and drink, and is aiways the result of inoculation through the mouth. While water and milk are the chief carriers of the germ, the history of the disease during the Spanish-American War shows that the work of flies is a more important factor in this connection than was formerly supposed. That dirt and filth are contributing causes to the extent that they harbor flies, is therefore evident. The theory of the evolution of putrefactive bacteria through successive generations into the bacillus of typhoid, while a plausible one, is not as yet accepted by leading sanitarians.

Neat and milk offer very favorable conditions for the growth of the typhoid bacillus and several instances are on record where extensive epidemics have been traced to an impure supply of the latter. In very many of such cases, however, infection has resulted from the use of cold water from a polluted well for the purpose of rinsing the milk cans. This practice, known to be a general one throughout the State, should be abandoned, as after the dairy utensils have been thoroughly scalded and put away in a clean place, secluded from dust and odors, any subsequent rinsing is unnecessary, and by avoidance of such the possibility of an infection through the milk supply is thus practically eliminated.

Especial attention might be called to the danger in the use of green vegetables, eaten raw, from truck gardens fertilized with night soil.

In cases where a public water supply falls under suspicion it is some times pointed out that fever is by no means confined to the users of the eity water. Admittedly this is often very true, 
yet, in view of the vile condition of many 16 well waters, on the farms as well as in the towns, there is nothing inexplicable about the circumstance.

That typhoid fever is an autumnal disease was formerly accounted for by the so-called "ground air" theory, which assumed that the germ laden air of the soil was forced out laterally into the cellars by the fall rains. The more modern "ground water" theory is based upon the concentration of germ life in the wells, and the drainage by such of a more extended area as a result of the lowering of the water level. The periodicity of the disease is now considered as being directly a function of temperature.17 It is probable that after a season especially favorable to growth in the soil the germs are washed into the water supplies by the heavy rains. As is well known, in many localities the disease is at its height during the winter season. In summing up the work of Sedgwick and Winslow, Hiss concludes 18: "Winter and spring epidemies are characteristic of those cities whose water supply is most subject to pollution; it is absent from communities which use filtered water, or water from adequately protected water-sheds."

The question some times arises why, if the water supply contains typhoid germs, the fever epidemic does not become molis wide-spread than it does. Two factors are responsible for this limitation. The first is referable to the devitalized condition of the bacillus as the result of a more or less prolonged existence in

16 The writer recently made a trip of inspection through a certain section of Morgantown unprovided with the city water supply. Instances were found to be numerous where, on an ordinary sized hillside building lot, the lower part of which faced the street, a well was located between the dwelling and an outhouse a few feet higher iil the rear.

17 "Statistical Studies on the Seasonal Distribution of Typhoid Fever in Various Countries and its Relation to Seasonal Temperatures." By William T. Sedgwick and Charles Edward A. Winslow. Memoirs American Academy of Arts and Sciences. Vol. XII, No. 5.

18 "Science," XVII, No. 434. 
the water. The second depends upon the theory of the annihilation of disease germs by certain organisms of the blood. such organisms normally finding their task an easy one in the case of the water-borne typhoid germs. In "predisposed subjects" or in cases where the individual is "run down" in health, the bloor leucocytes of such are incapable of successfully combating the fever germs, being finally overcome by the toxins generated by the latter. On the other hand, where subjugation is but partial a "light" case of fever is the result.

It is asserted 19 that filtration, either slow sand, or mechanical (with coagulation), will, on a conservative estimate, reduce typhoid fever fifty per cent. In the case of the city of Iawrence, Mass., using Merrimac River water, the reduction was from 131 per 100,000 in 1890 , before filtration was introduced. to 17 per 100,000 in 1902; in the case of Albany, N. Y., the rate decreaserl from 165 per 100,000 before filtration, to 27 per 100,000 for 1902 . The city of Pittsburg uses Allegheny River water without filtration, and its typhoid death rate is said to be at present the highest recorded for any city of the world. To what extent the water of this city is responsible for deaths in other towns, it would be impossible to estimate.

19 Ohio Sanitary Bulletin No. 7. 


\section{REFERENCES.}

For a further discussion of the subject of water supply and the sanitary principles involved, the following literature may be consulted: Mason: "Water Supply"; Hazen: "Filtration of Public Water Supplies", Fuertes: "Water Filtration Works"; Fuertes: "Water and the Public Health"; Hill: "Public Water Supply"; Turneaure and Russell: "Public Water Supplies"; Abbott: "Hygiene of Transmissible Diseases"; Whipple: "The Microscopy of Drinking Water"; Smith: "Sewage Disposal on the Farm and the Protection of Drinking Water, (Farmer's Bulletin No. 43, U. S. Department of Agriculture) ; Morse: "The Farm Water Supply', (Bulletin No. 53, New Hampshire Experiment Station); Nelson: "The Proper Disposal of Sewerage Wastes in Rural Districts", (Bulletin No. 166, New Jersey Agricultural Experiment Station) ; Blair: "Drinking Water", (Builetin No. 161, North Carolina Agricultural Experiment Station). 


